\title{
الفنون الثعبية فى البيئة المصرية كمصدر لاثراء التصميمات الزخرفية
}

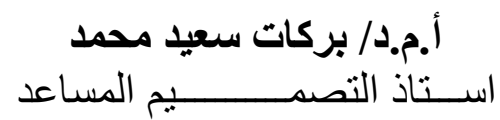

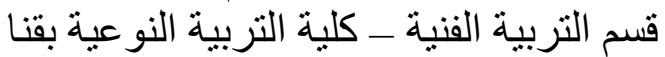

جامعة جنوب الو ادى

التصميم الزخرفى نوعية من التصميمات المسطحة التى تهدف إلى تناول العناصر تناو لاً زخرفياً

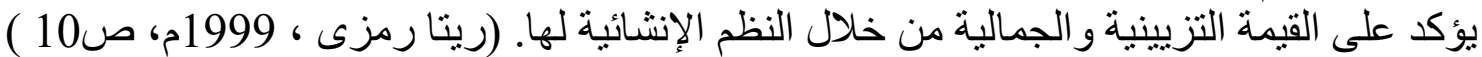

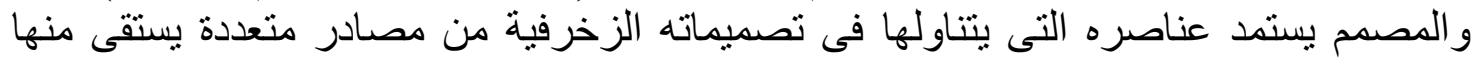
ويستلهم أفكار جديدة تناسب العمل الابتكارى.

ومن هذه المصادر , الفن الثعبى ـ فالفن الثعبى هو فئس فن أبدع بواسطة طبقة بسيطة وبتقاليد

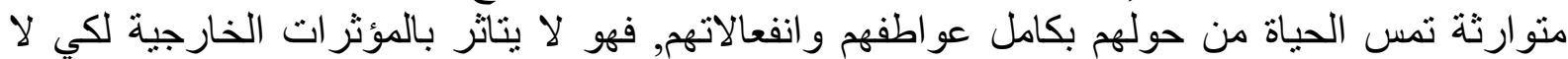

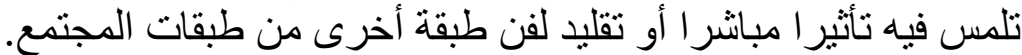

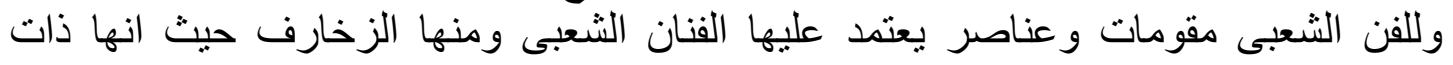

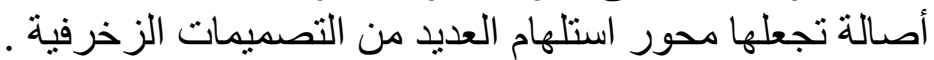

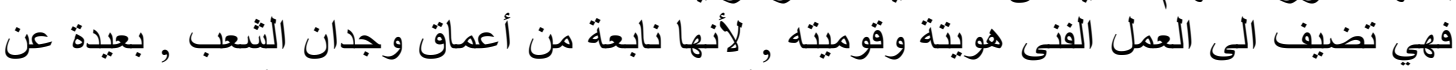
التأنق و الترف , عظيمة فى قوتها وقوية فى بساطتها. أيضا ذات قيمة جمالية عالية بالأضافة الى قدرتها

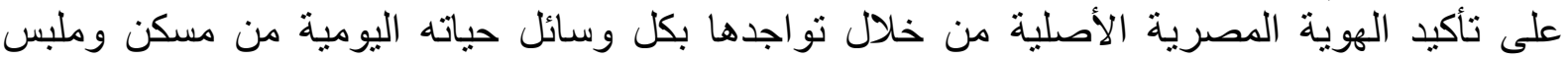


و ادوات ترتبط بمعيشته وذات صلة ببيئتة المحيطة ـو وهى فى النهاية تعتبر مصادر للتصميمات الزخرفية

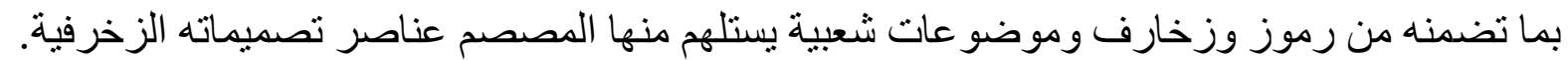

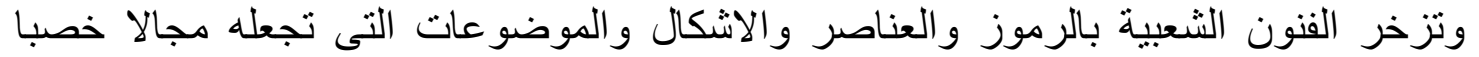

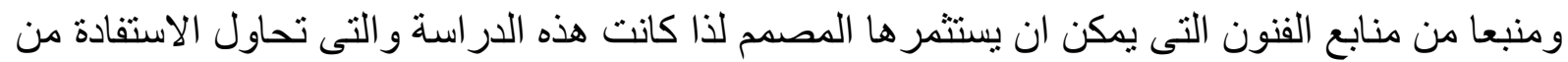

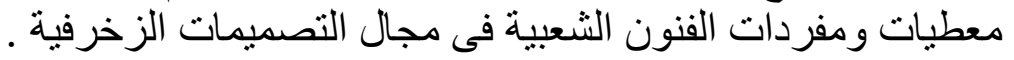
مشكلة البحث : معنيات

مع تعدد وتتوع عناصر ورموز وموضوعات الفنون الثعبية فان الحاجة لاسثمار ذلك باتت مهمة

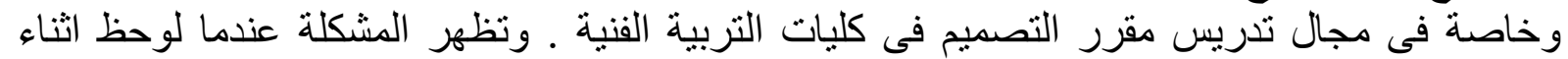

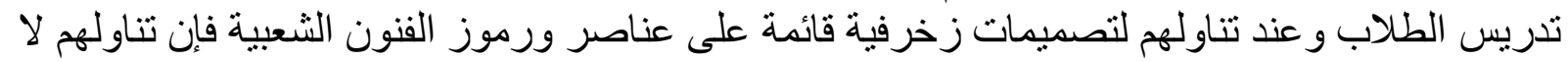

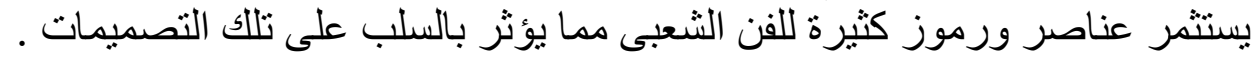

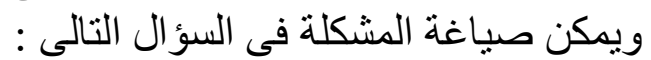

ما امكانية استثمار عناصر ورموز الفنونة الفئن الثعبية كمصدر لاثر اء التصميمات الزخرفية.

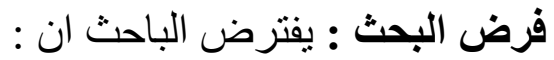

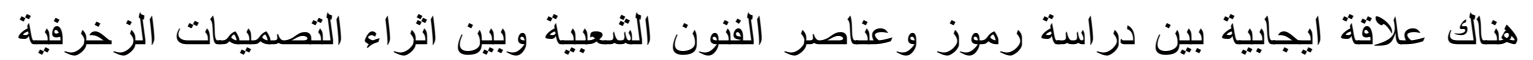

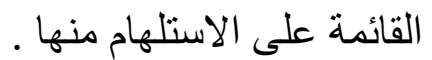

$$
\text { أهداف البحث : تتحدد أهداف البحث فيما يلى : }
$$

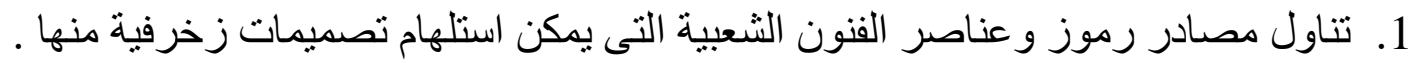
2. دراسة رموز وعناصر الفنون الشعبية كمصدر لإِثر اء التصميمات الزخرفية .

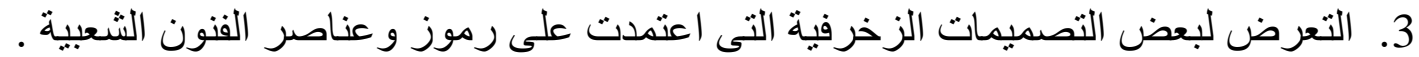

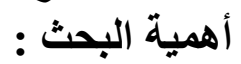
تتضح اهمية البحث فى تناول رموز وعناصر الفنون الثعبية كمجال خصب من مجالات الفنون

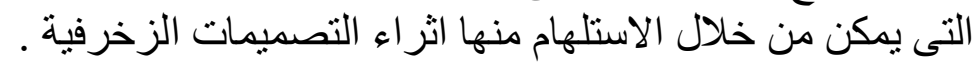

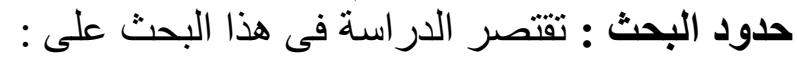

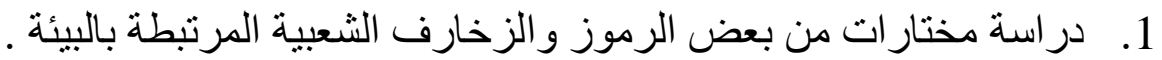

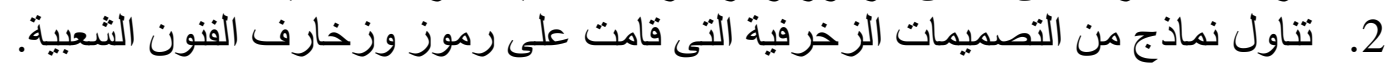

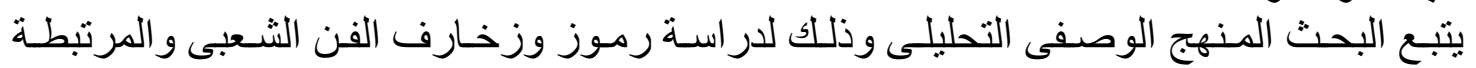

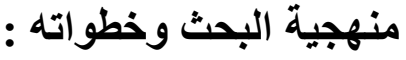
بالبيئة. خطو ات البحث : تتحدد خطو ات البحث النظرية فى المحاور التالية :

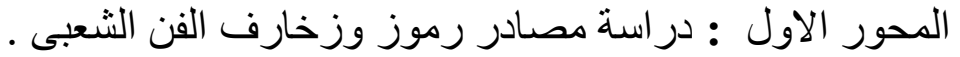

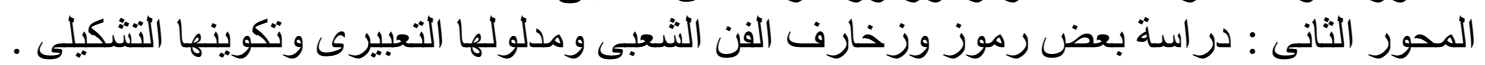

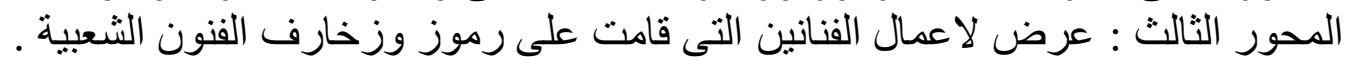

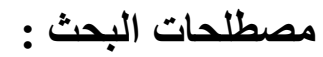
• الفنون الشعبية : الفن الثعبى فن بسيط التكوين لا تعقيد فيه ، فن ابتكر بالسليقة قريب من الطبيعة

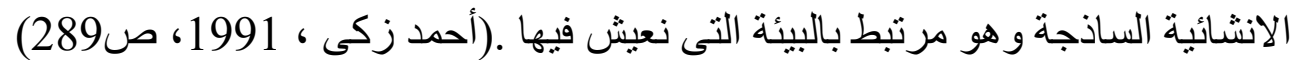

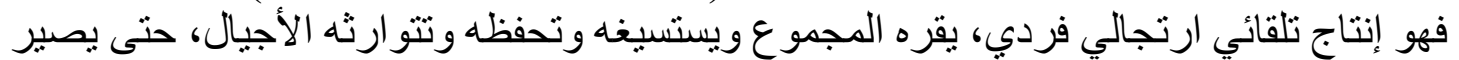

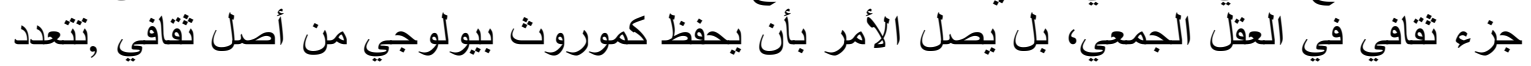

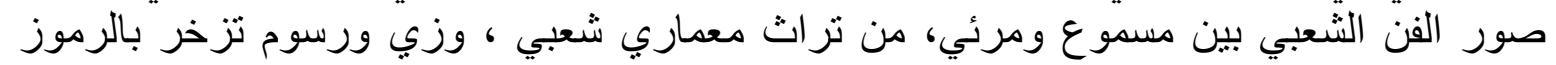

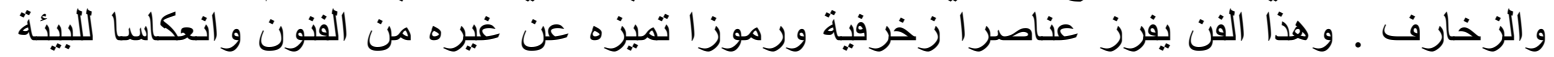
و الحالة الثقافية للمجتمع الذى ينشأ فيه .

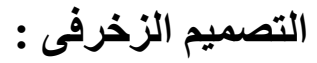


تعددت الآر اء حول مفهوم التصميم الزخرفى و الذى نذكر منها :

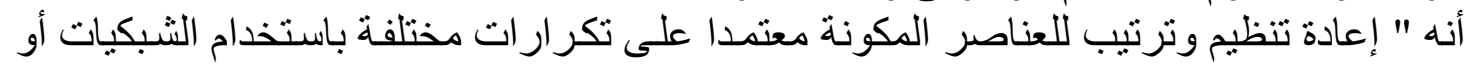

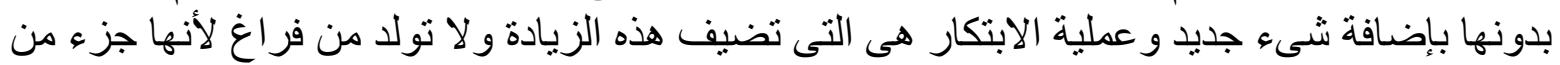

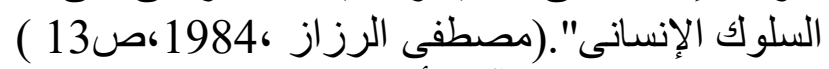
وفى تعريف آخر أنه " هو نظام متكامل لتحقيق فكرة محددة من خلال مفردات تشكيلية قائمة على الإنى عدد من الأسس البنائية بهدف تحقيق الدلالات التعبيرية وتعكس ما بداخلها من قيم جماليـة.(الخولى و أحمد فيد

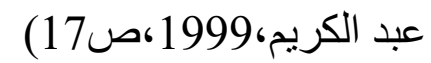
ورغم تعدد تلك الآر اء إلا أنها تدور حول محور مشترك وهو أن التصميمات الزخرفية تقوم على ألى

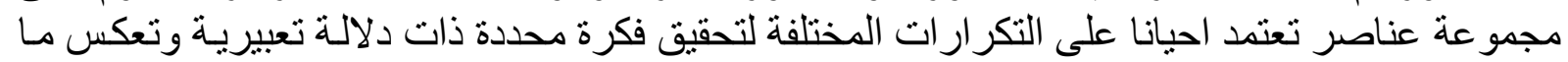

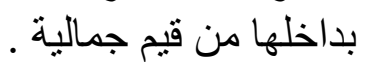

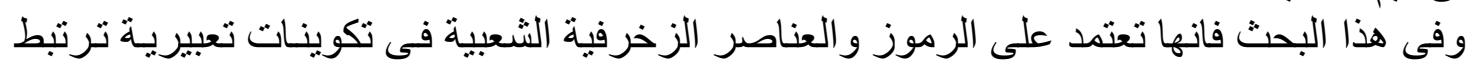

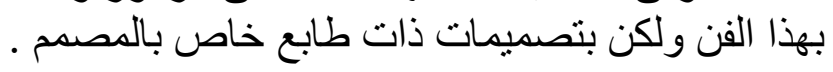

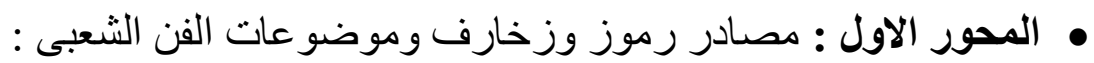

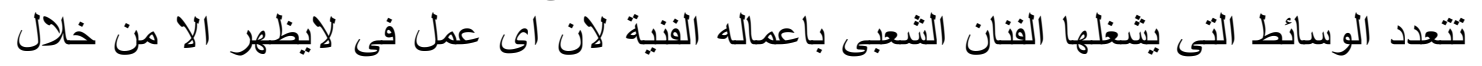

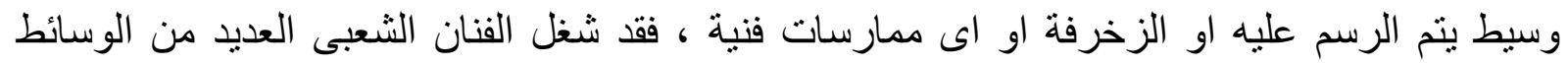

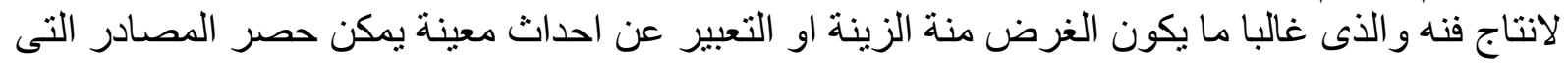

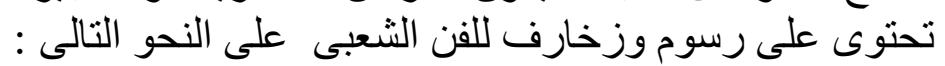

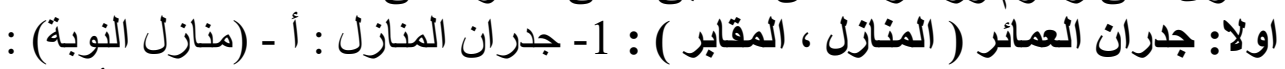

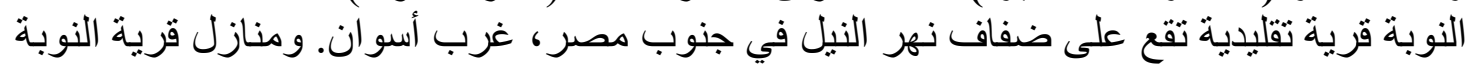

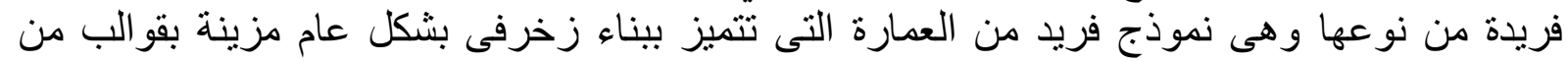

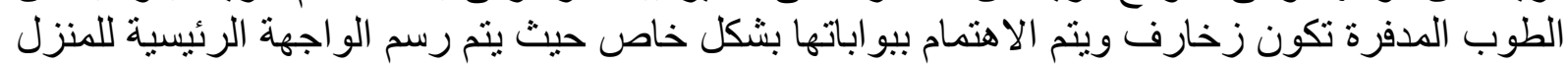

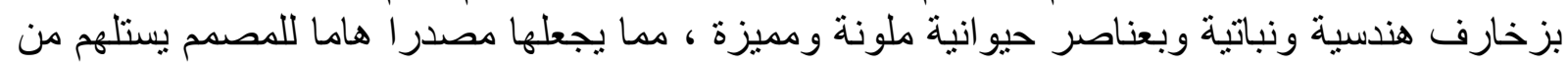

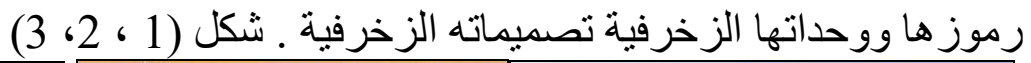
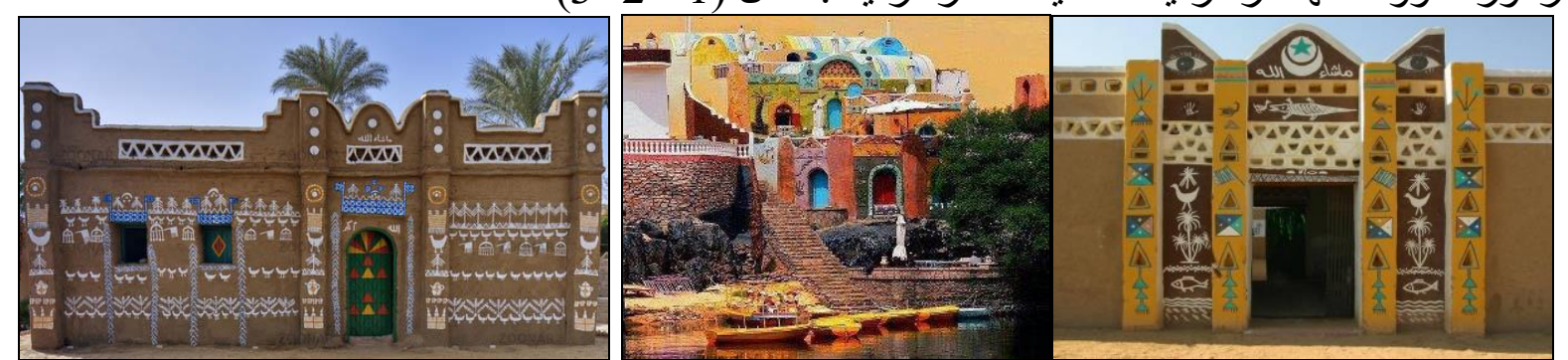

شكل (1 ، 2، 3) نماذج من المنازل النوبية التى تعتبر مصدر ا من مصادر

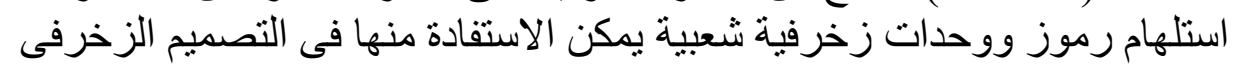

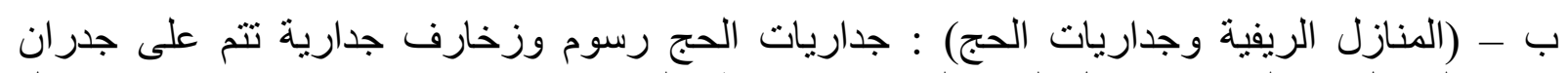

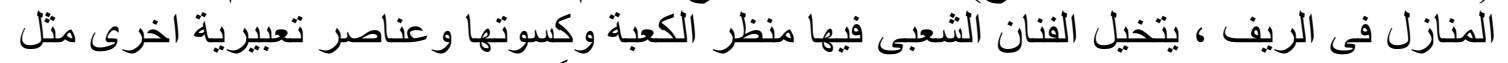

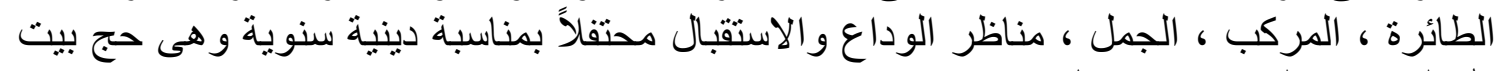
الله الحر ام كتقليد سنوى. شكل (4، 6، 5، 5)
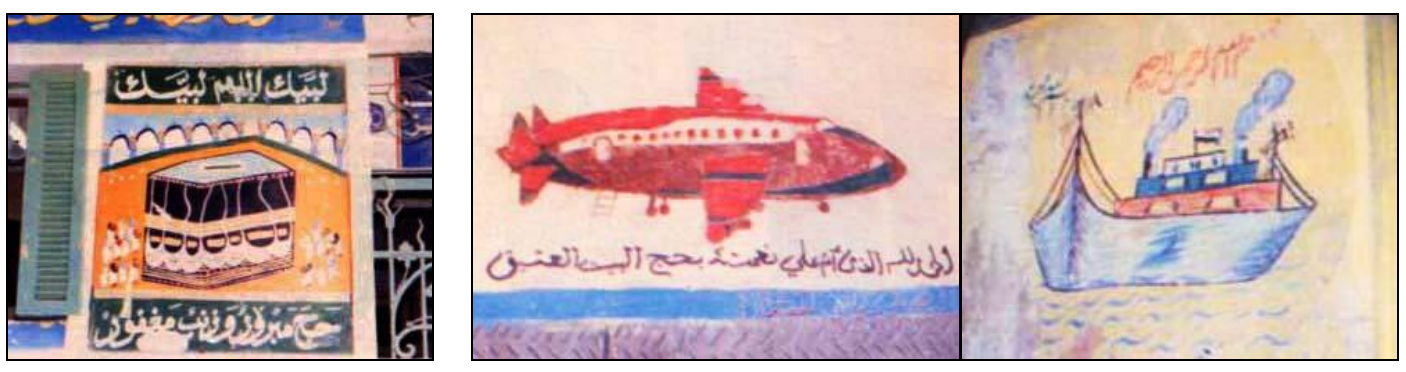


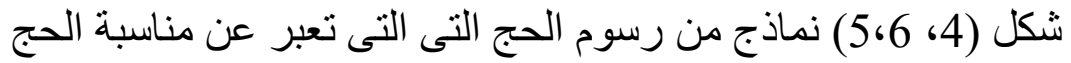

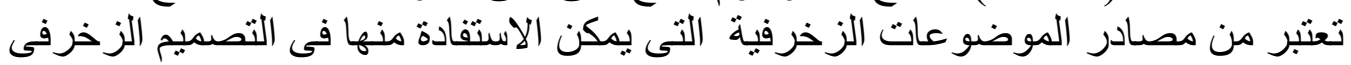

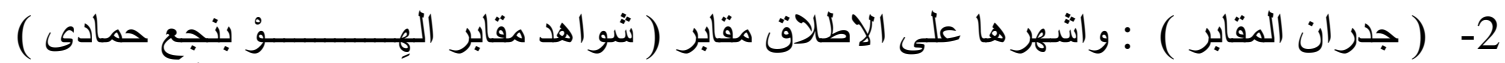

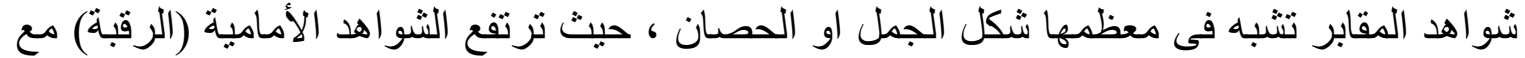

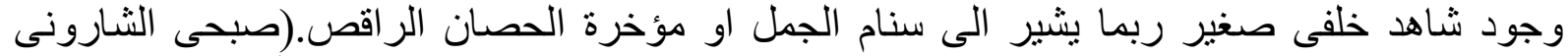

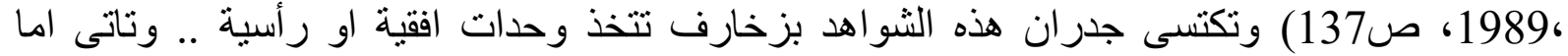

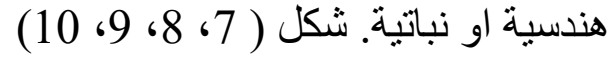
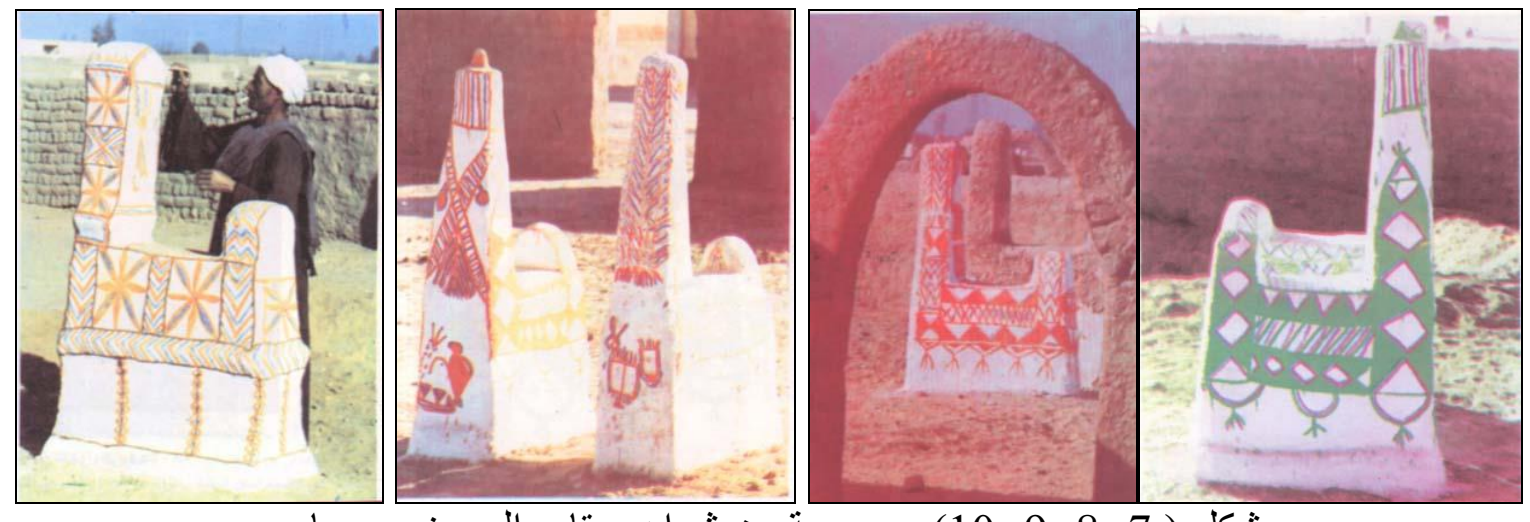

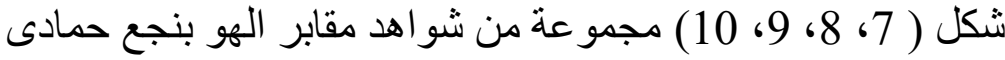

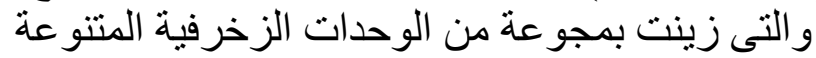

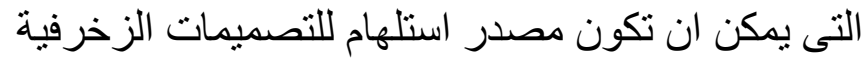

ثانيا : المشغولات المتنوعة :

1- (الأشغال الخشبية ) : مثل الأبو اب , الثبابيك, الصناديق الخشبية و الأثاث و عربات البد , عربات

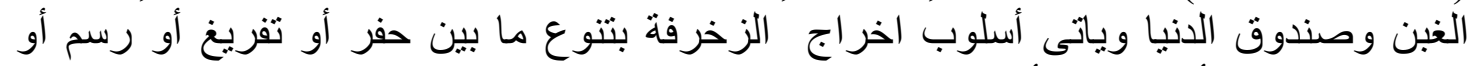

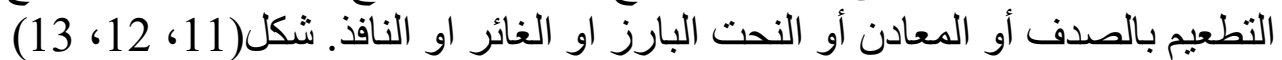
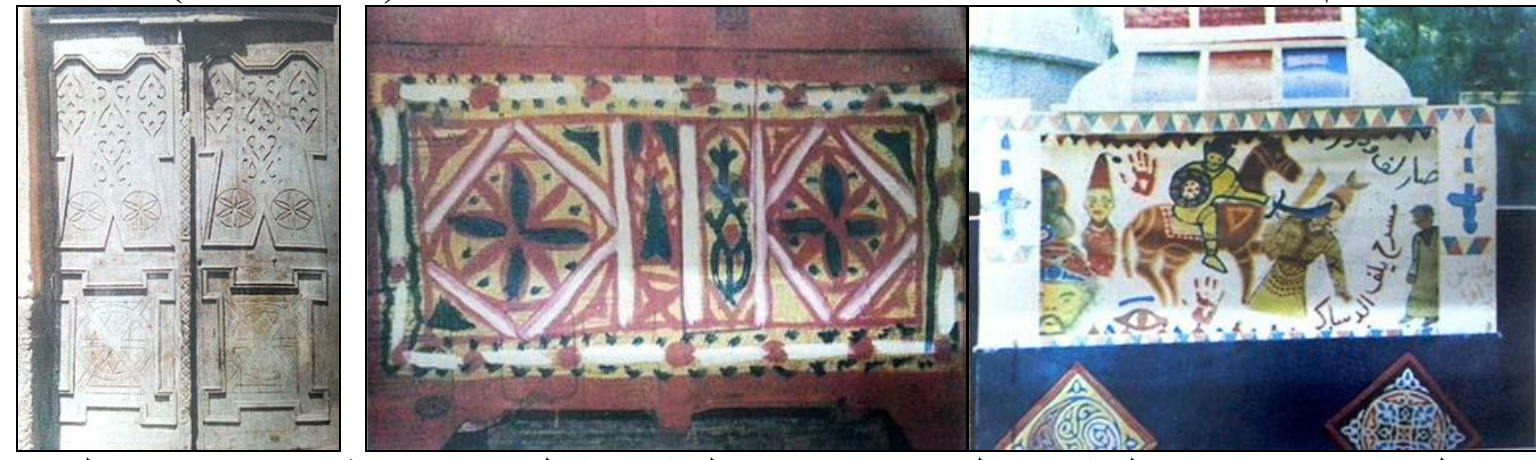

شكل (11) سحارة من الخشب شكل (12) باب من الخشب شكل (13) عربة غبن وصندوق الدنبا

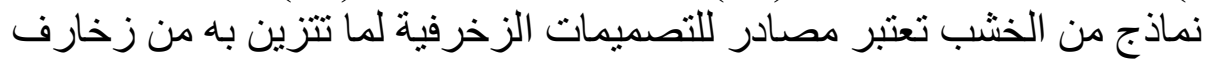

2- أشغال المعادن: أهمها الحلى وادوات الزينة , و الأطباق و الأباريق والصو انى والأكواب و غير ها من

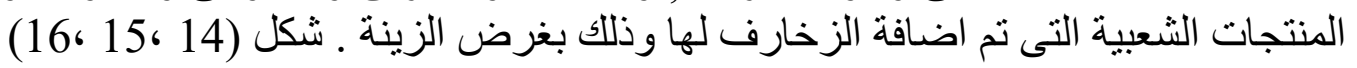




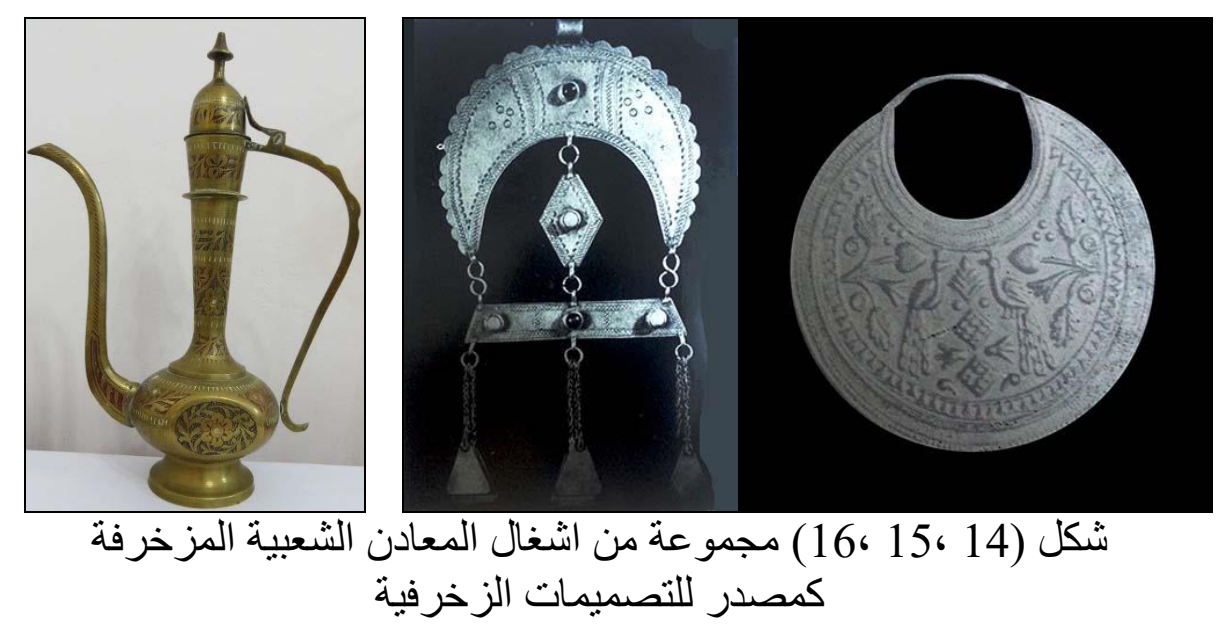

3- الفخار و الخزف : كالقلل التى ظهرت فى العصر الاسلامى والتى احتوت على انواع متعددة من الزخارف سو اء من الداخل و التى تعرف بشبابيك القلل أو الخارج ـ شكل فئ ( 17 ، 18، 19)
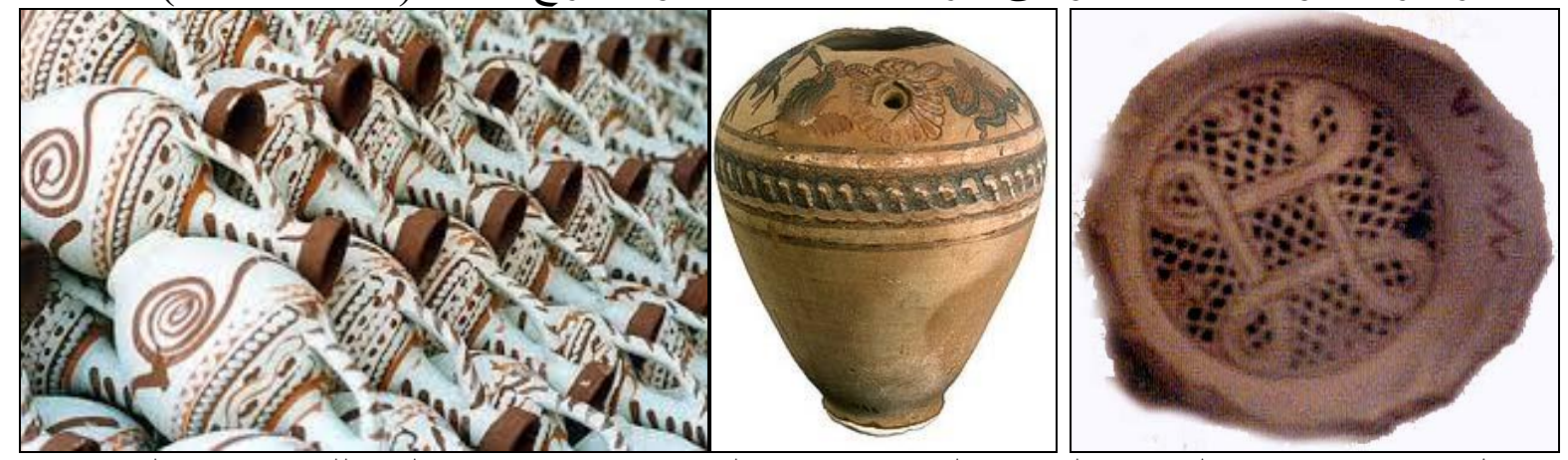

شكل(17 ،18، 19) الفخار والخزف الشعبى وتتوع الزخارف كمصدر استلهام للتصميمات الزخرفية 4- المنسوجات الشعبية : ونتشمل الملابس والمفروشات من كليم وسجاد واعمال الخيامية المزخرفة

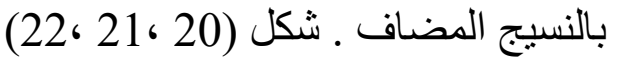
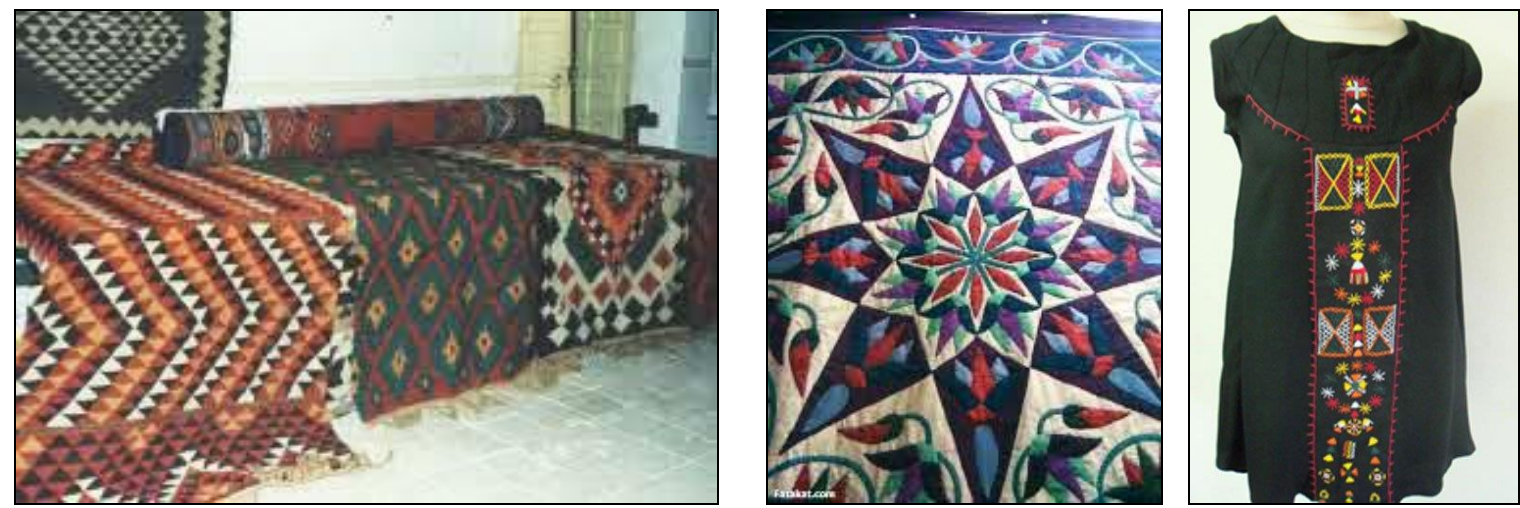

شكل (20 ، 21 ،22) الخيامية و الازياء و السجاد وماتزخر به من زخارف تثرى التصميمات الزخرفية

5- الخوص ومنتجات الجريد وخامات اخرى : تتعدد وتتنوع منتجات الفنان الثعبى فى هذا المجال من

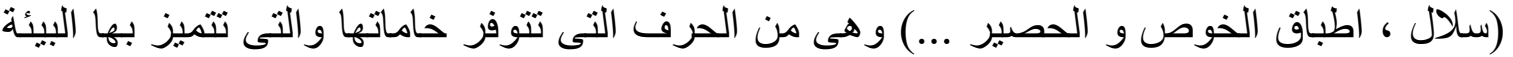
الريفية و النوبية ـ. وتمتعت تلك المنتجات بالزخارف التهن التى تزينها وخاصة الاطباق و والسلال باسلوب

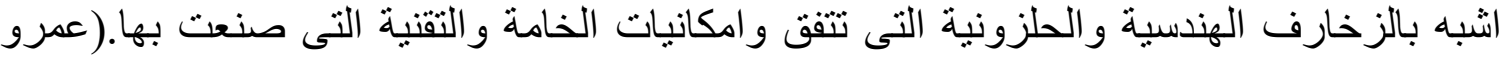

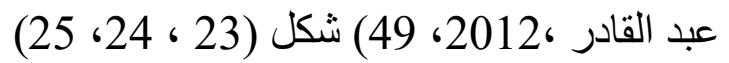



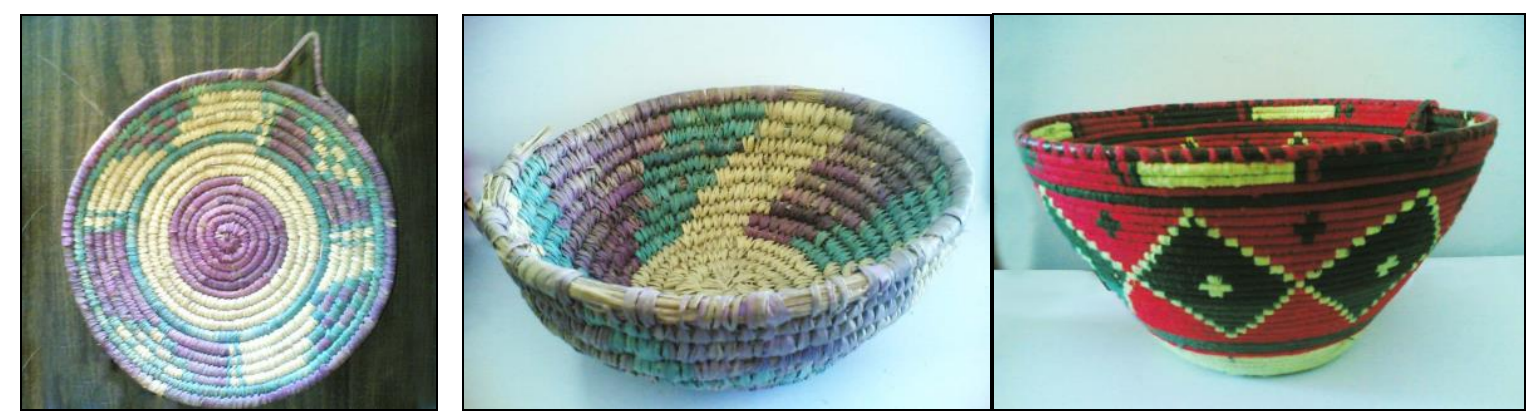

شكل (23 ، 24، 25) مجمو عة من المنتجات الشعبية و التى تزينها الزخارف

و التى تعد مصدر ايثرى التصميمات الزخرفية التهية

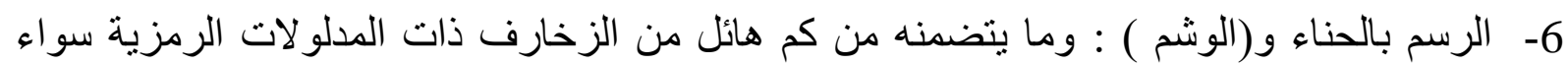

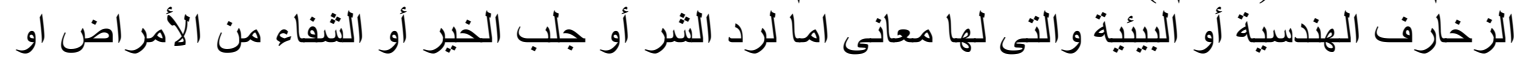

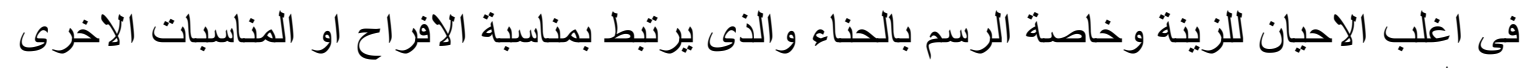

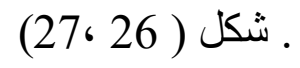
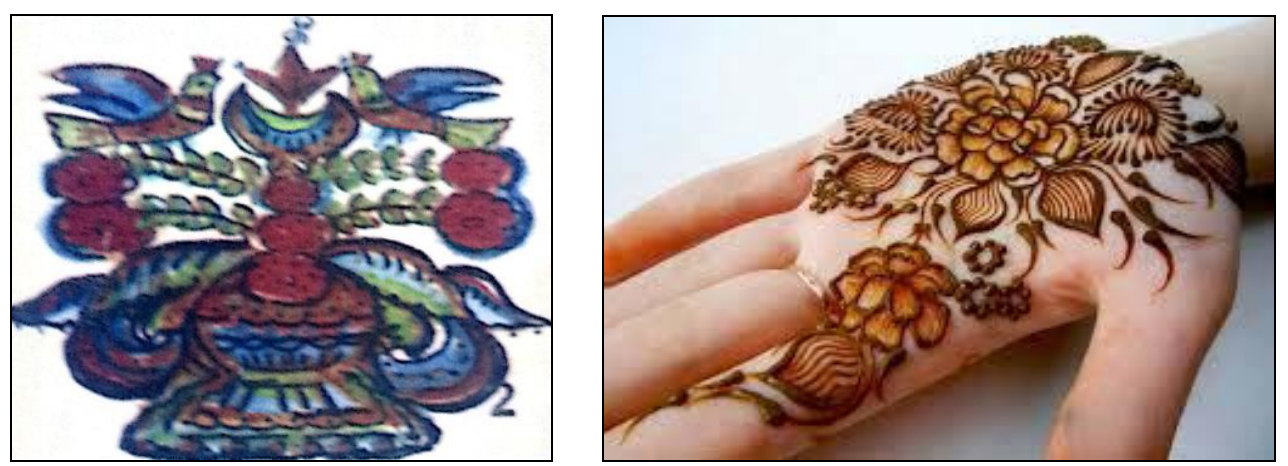

شكل ( 26 ،27) وحدة وشم ورسم حناء وما تتضمنه من زخارف يمكن ان تثرى التصميمات الزخرفية

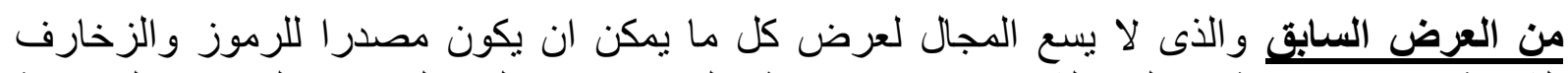

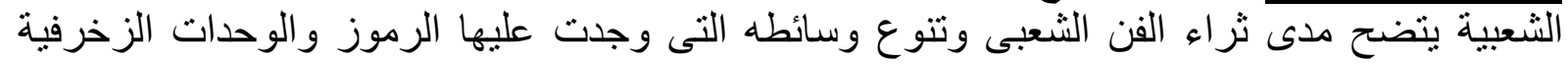

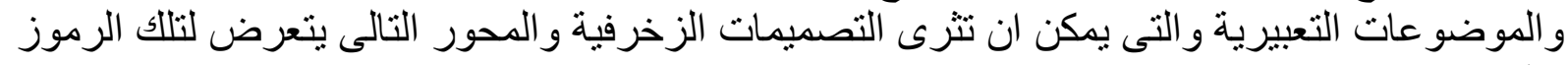

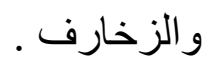

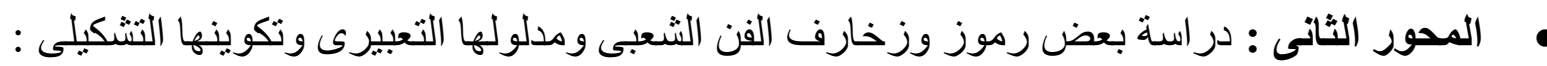

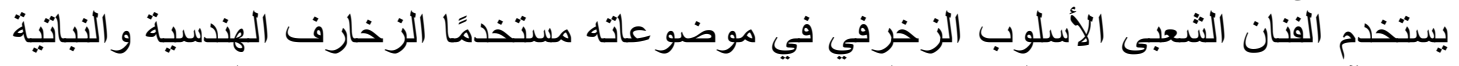

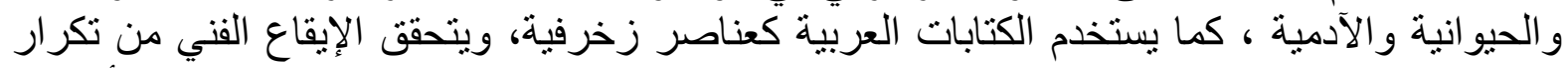

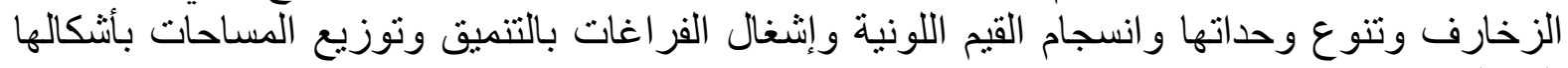

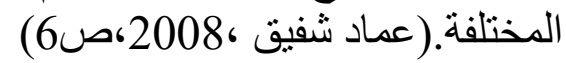

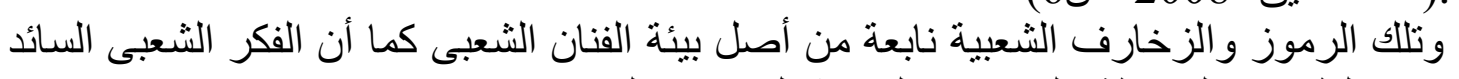

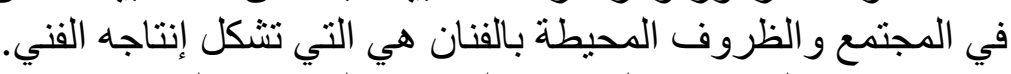

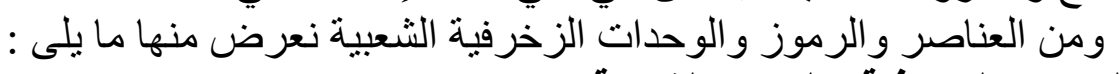

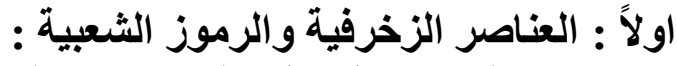

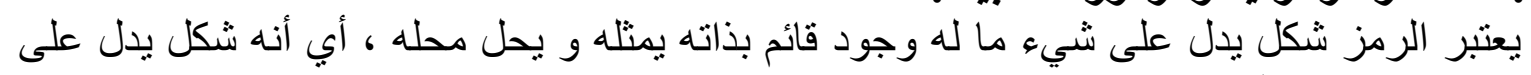

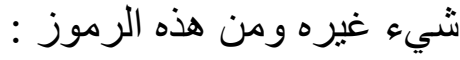

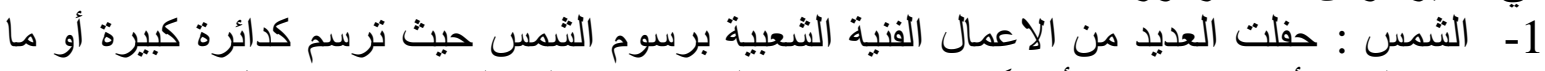

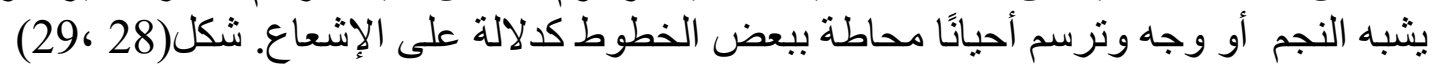




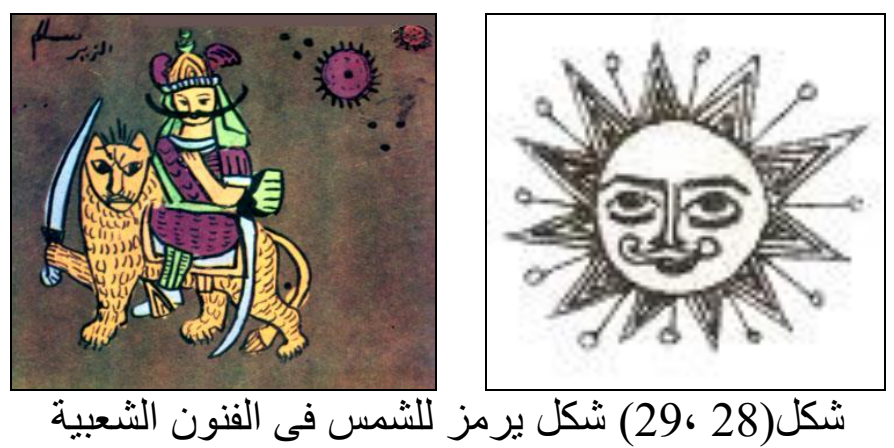

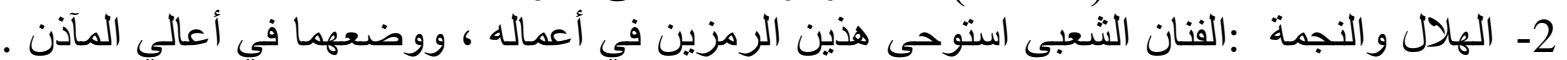

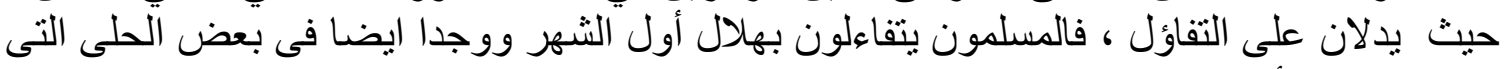

تنزين بها المر أة الثعبية حيث بما يجعل لهما دورًا هامًا في وجدانه ـشكل (33:30)
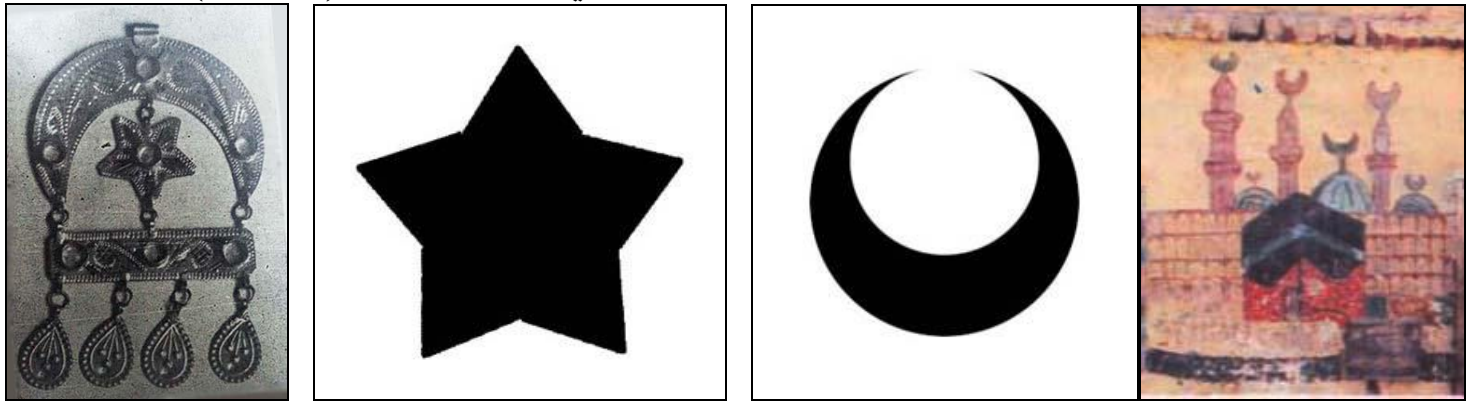

شكل (33:30 الهلال و النجمة من الرموز التى استهمها الفنان الشعبى التهي

و عبر بها عن موضو عاته ويمكن ان تثرى التصميمات الزخرفية عند استلهام تللك الرموز

3- النخيل : وهو رمز مقد ورمز للخصب و الرزق. وقد تناولها الفنان الثعبى فى العديد من موضو عاته حيث انها تدل على رئى الخير و الحياة .شكل (34 ، 35)

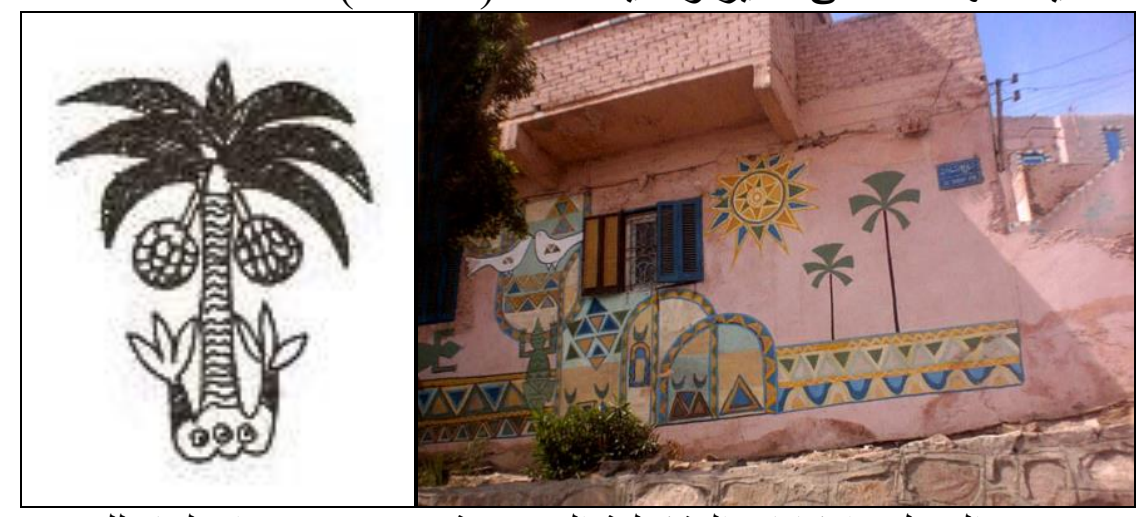

شكل (34 ،35) رمز النخيل وامكاناته التشكيلية الزخرفية وهى مصدر استلهام للتصميمات الزخرفية

4- الأبريق : وهو رمز للطهارة و الوضوء ويبعد الثر و الحسد وكثيرًا ما يرسم على واجهات المنازل

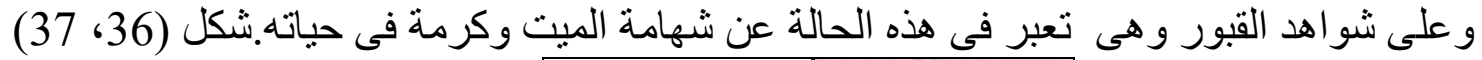

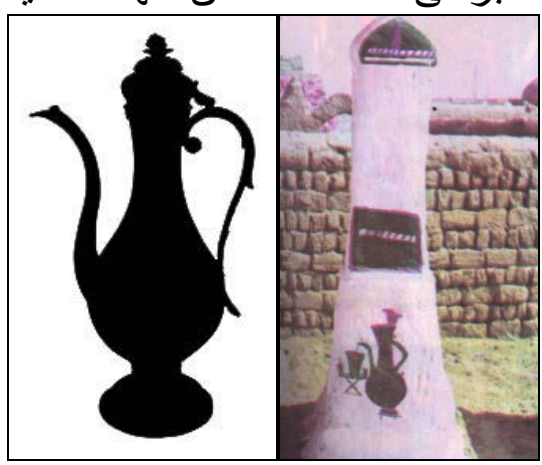


شكل (36، 37) رمز الابريق يدل على الثهامة و الكرم و يمكن الاستلهام منها فى التصميم الزخرفى 5- الكف و العين : صور الفنان الثعبى الكف كرمز لإبعاد الحسد وشر العين ولذللك يقرن رسم العين

برسم الكف فيرسم الكف مفتوحًا في وسطه عين ونكتب تحتها (خمسة وخميسة). شكل (38:40 )

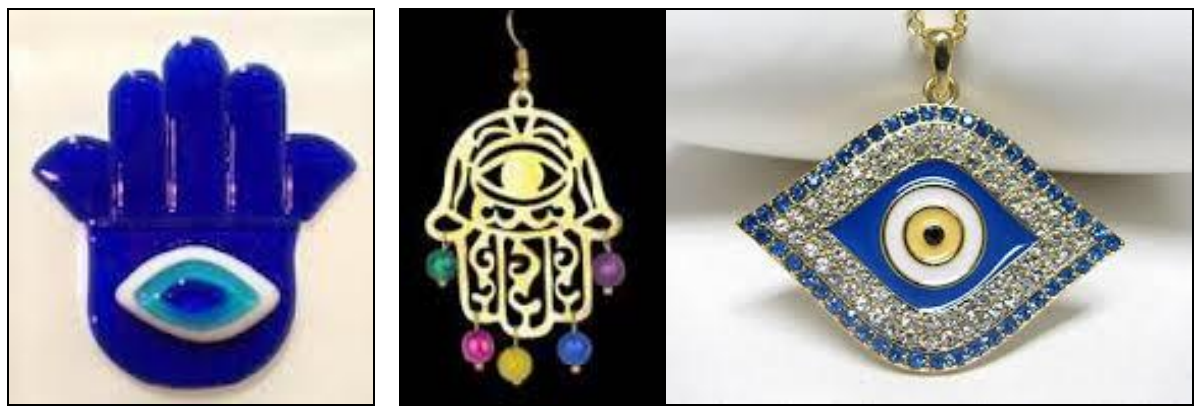

شكل (40:38 ) مجمو عة من مكملات الزينة التى تمثل شكل الكف و العين

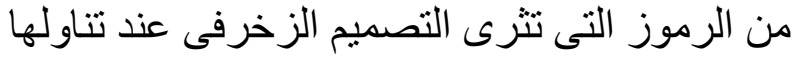

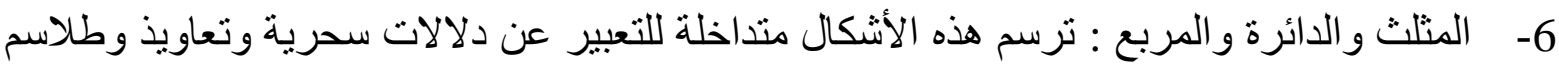
كما يمثل المربع والدائرة القدسية و الجلال.

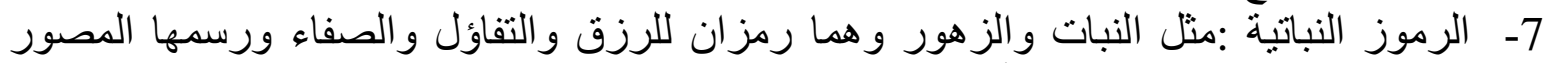

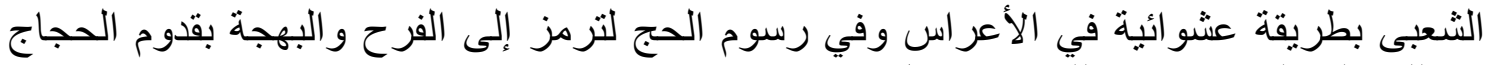

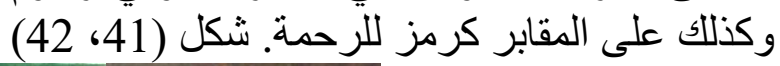

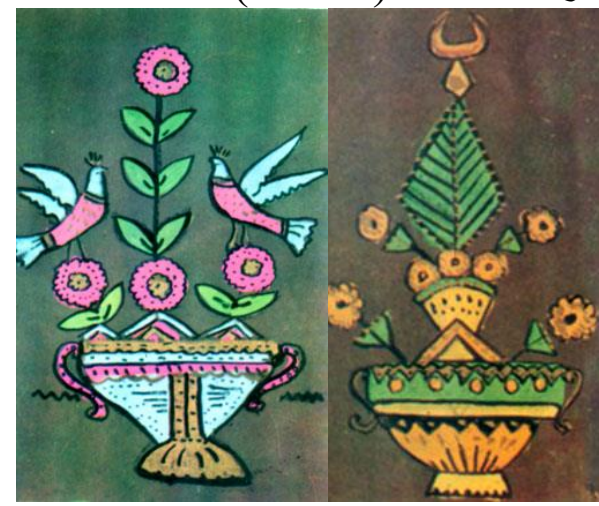

شكل (41، 42) الرموز النباتية فى الفن الشعبى تثرى التصميمات الزخرفية عند الاستلهام منها

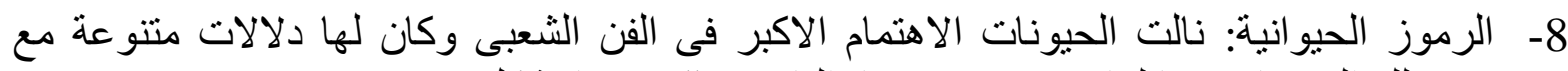

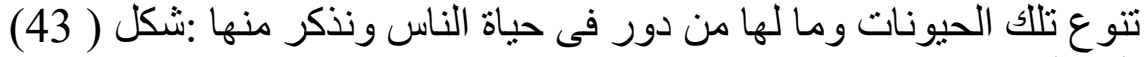

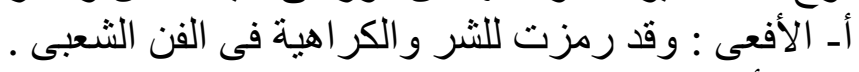

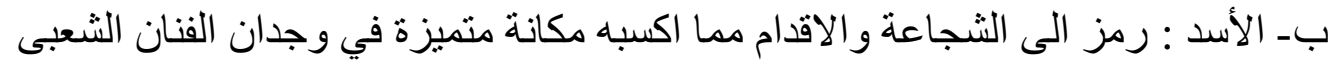

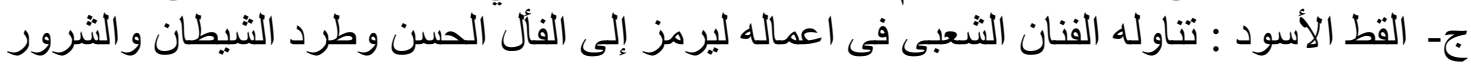

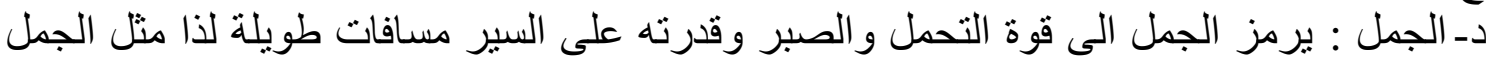

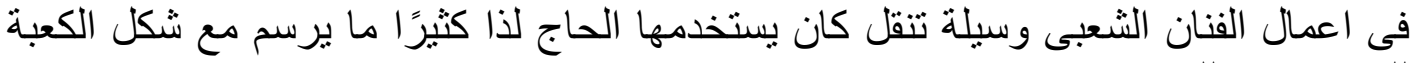

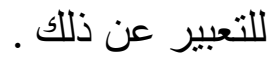
هـ السمكة : وترمز للعة الرزق وجلب الحظو الخصوبة. 


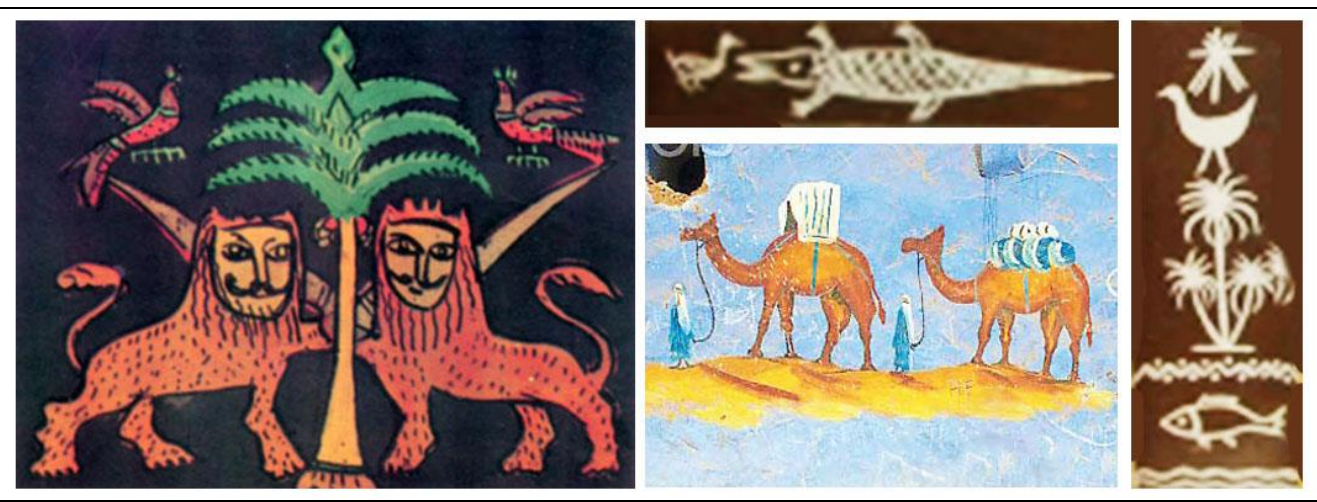

شكل ( 43) مجمو عة من الرموز الحيو انية التى وجدت فى موضو عات الفنون الشعبية

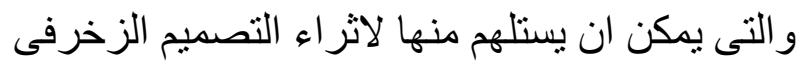

9- عروسة المولا ولعب الحلوى : رموز شعبية ارتبطت بذكرى سعيدة عند المسلمين هى ذكرى مولد

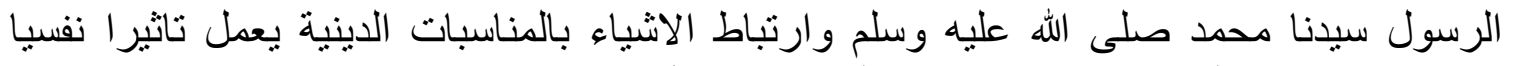
و عاطفيًا قويًا عند الجماهير فى احياء هذه المناسبة ـ شكل (44)

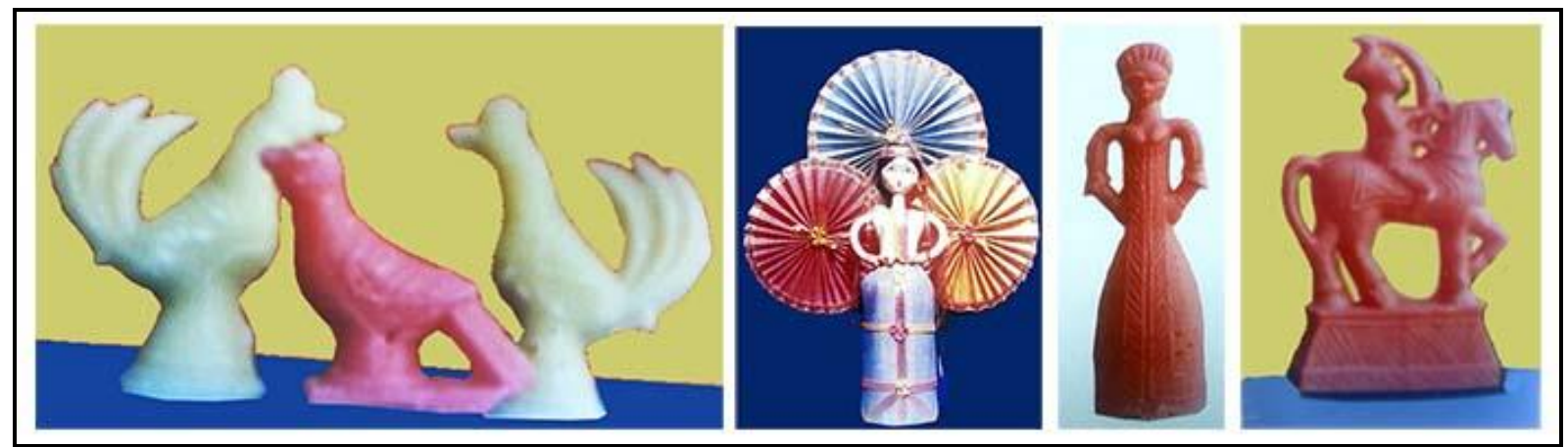

$$
\begin{aligned}
& \text { شكل ( 44) عروسة المولد ولعب الحلوى من رموز و عناصر الفنون الشعبية }
\end{aligned}
$$

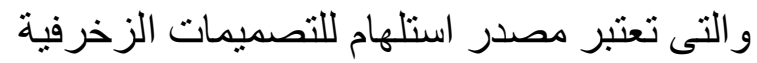

الخلاصة : ما تم عرضه من رموز وعناصر زخرفية شعبية هو اليسير منها فان الفن الشعبى يزخر

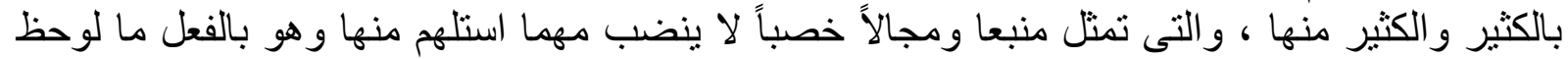

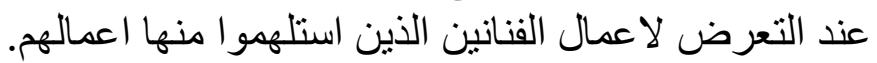
• المحور الثالث : عرض لاعمال لاعمال الفنانين التى قامت على الاستلهام من رموز وزخارف الفنون الثعبية:

شجعت السمات التشكيلية لعناصر الفن الشعبى من زخارف ورموز الكثير من الفنانين

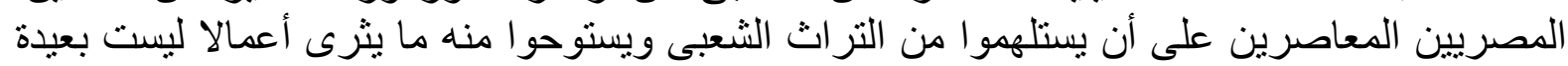

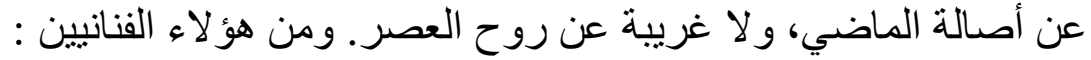

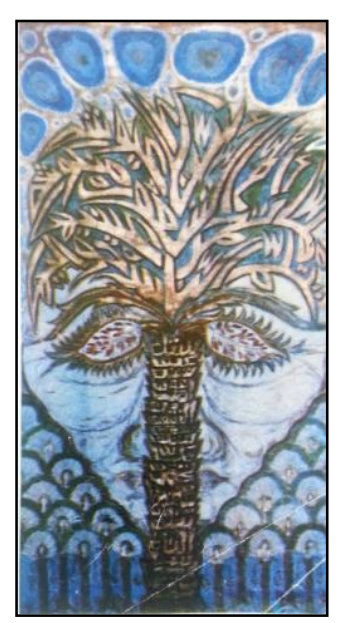

$$
\text { - }
$$

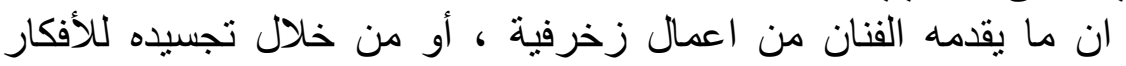

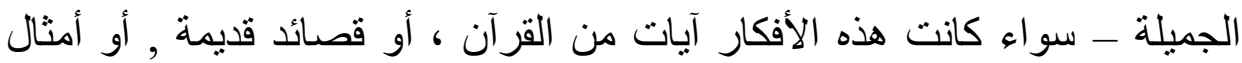

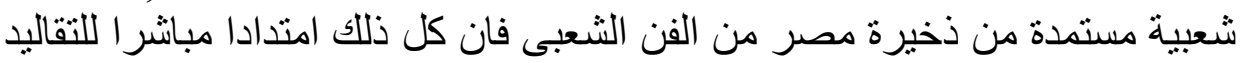

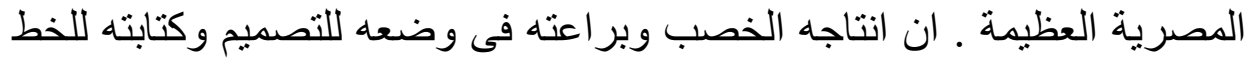

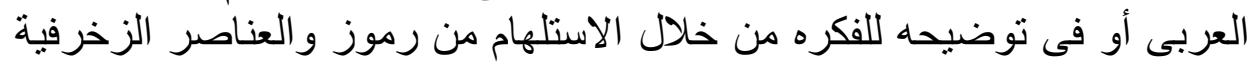
للفن الشعبى جميعها تعكس البهجة التى يشعر بها فئى تناوله لهن لتر اثذه المحلى.(صفاء

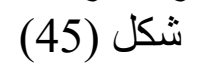

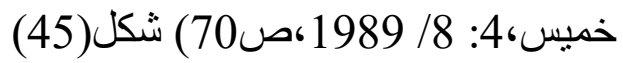


- الرموز و العناصر الشعبية المستلهمة : استلهم الفنان خميس شحاته رموز و عناصر زخرفية متنوعة

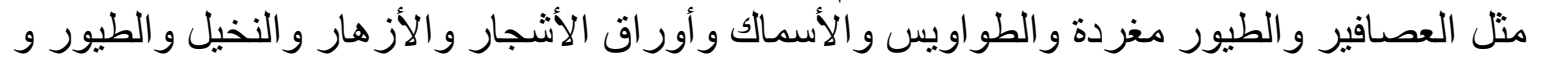

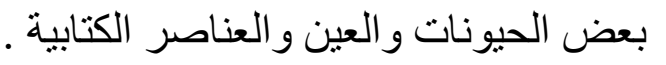
تاثز الفنان بالفن الشعبى و البيئة (الاستلاهام):

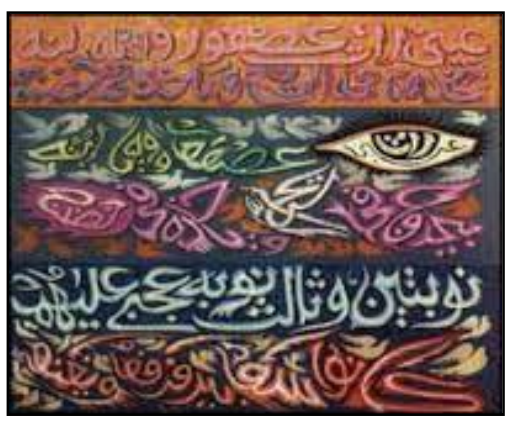

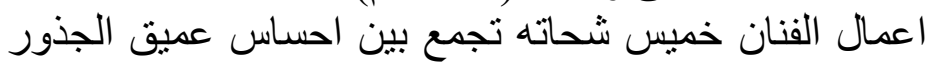

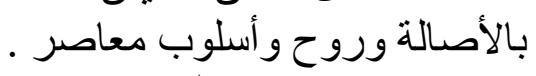

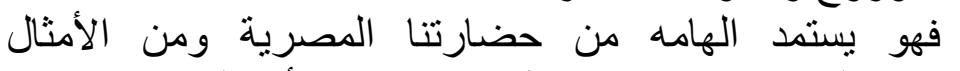

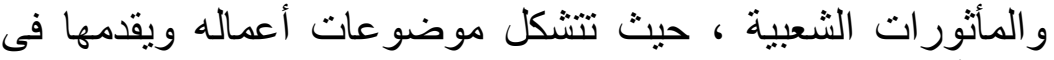

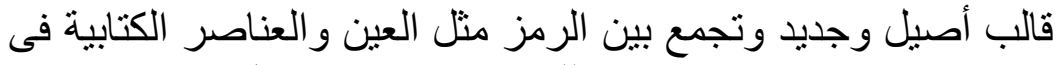

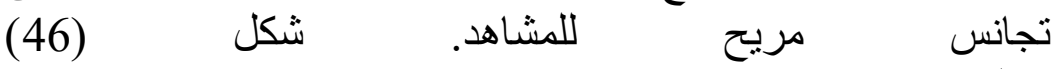
شكل (46) تجانس)

فالعناصر و الرموز المكونة لاعماله فى بعض الإحيان تصور

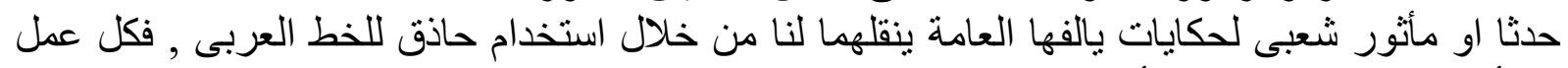

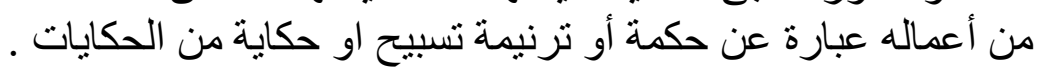




\section{-}

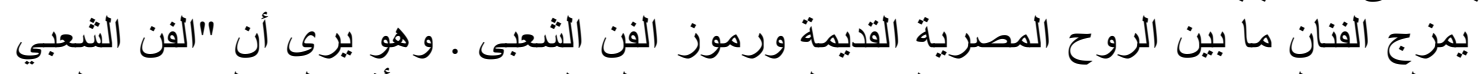

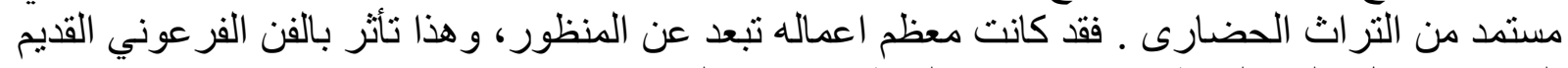

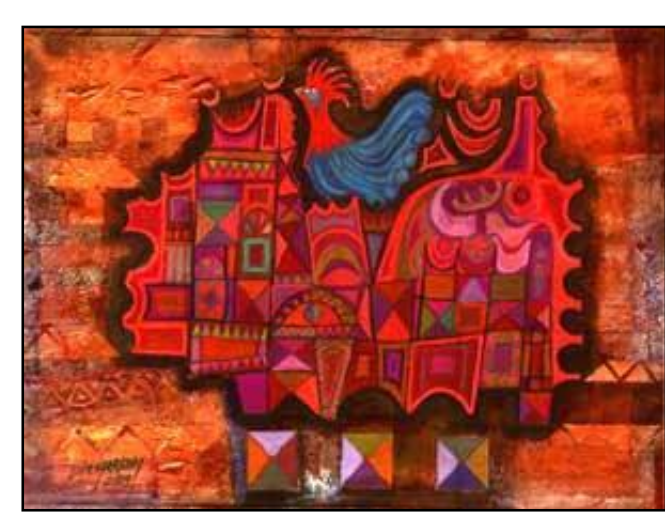

المستلهمة : الموز

تنوعت الرموز و العناصر الزخرفية النتى النئ

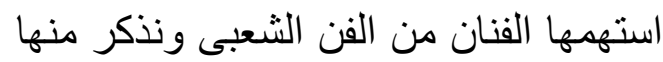
سبيل المثال لا الحصر ( الطيور ، النخيل ، وحنيل

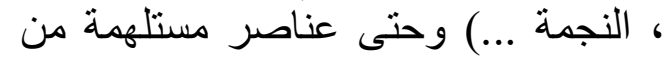
المنازل التى تشبه المنازل النوبية .

بالفن الثنبى و البيئة (الاستلامام): الفنان مفردات الثقافة الثعبية والجئمالية الثمالية

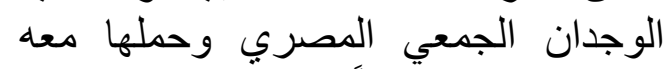

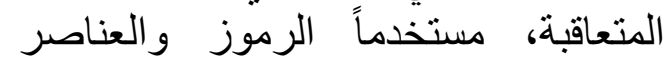

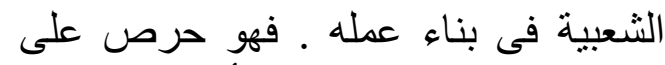
إيقاعات الفنون الثعبية ، وكأن تلك الرية الرموز

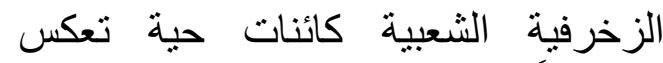
حضارياً عريقا لبصمات الإنسان والفية الفنان المصري، وتتناغم هذه العناصر وتتحول الإنسان ولفان

متناسقة. شكل ( 48، 49)

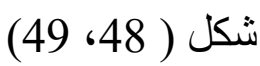

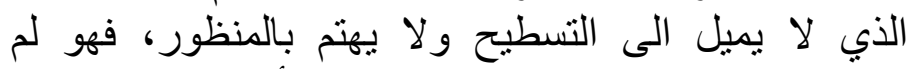

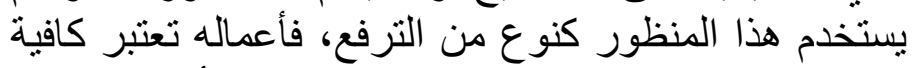

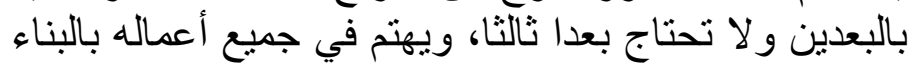

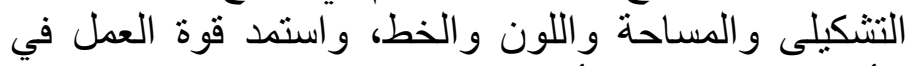

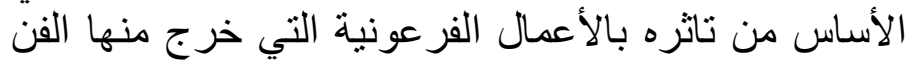

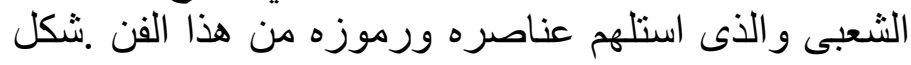
شكل (47)

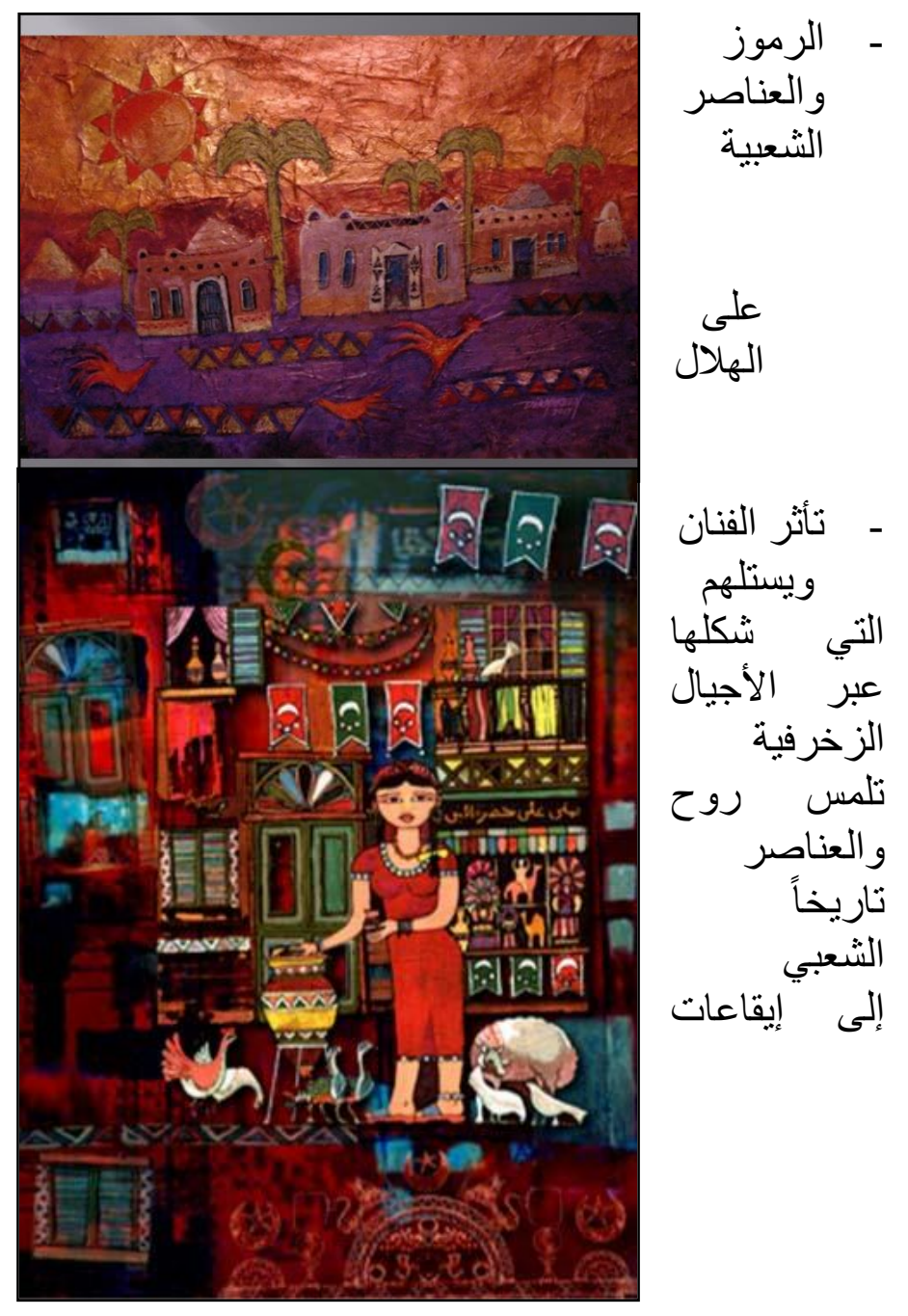




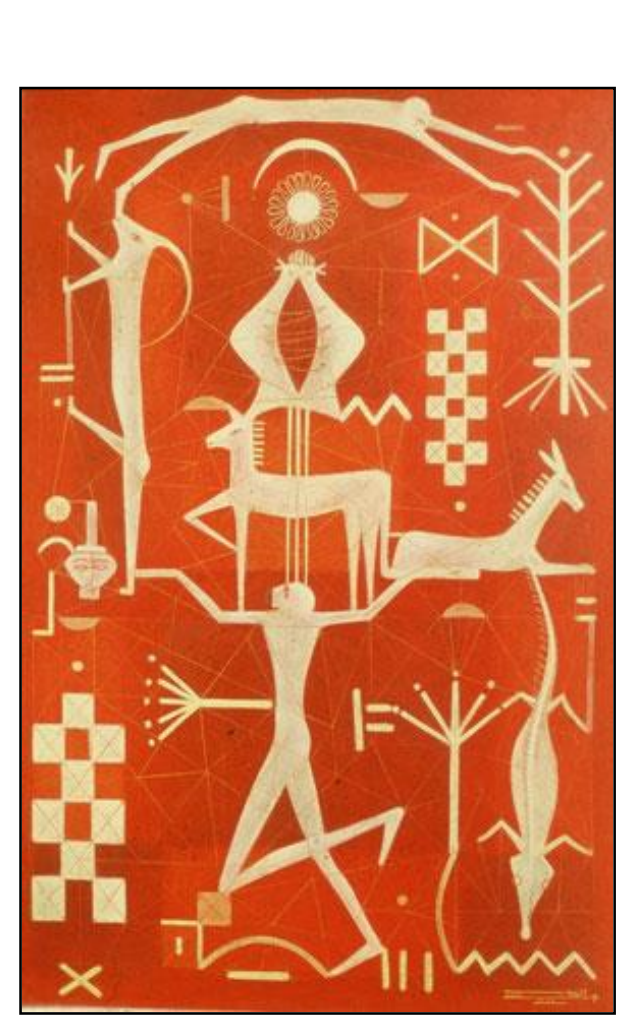

• - عبد الوهاب مرسيى الفنان التشكيلية : و التجديد وإن كانت الثوابت عنده واحدة فهو بنظر إلى التى التاريخ

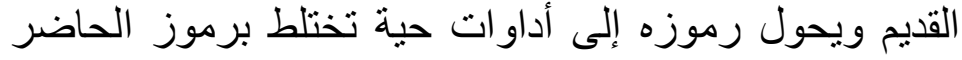

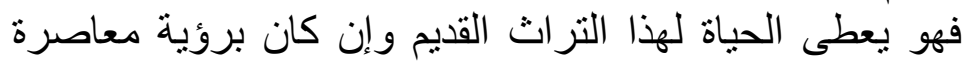

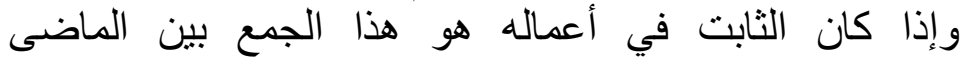

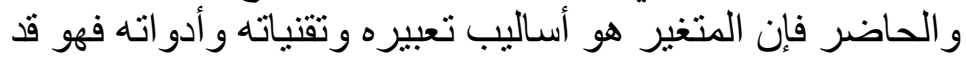

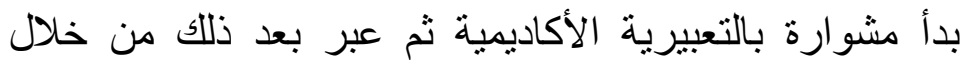

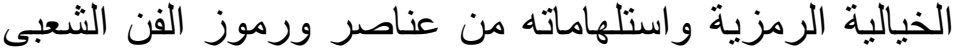

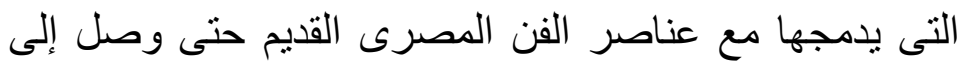
قدر يجمع بين التجريد وذلك الخيال وليس هناك شئك في أنى أنه

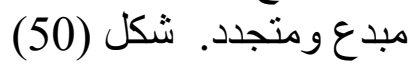

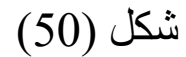

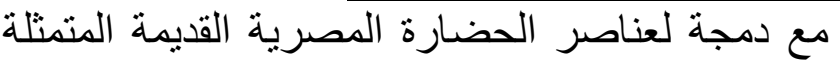

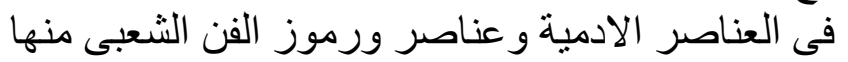

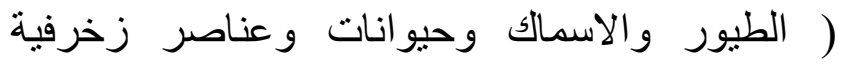

$$
\text { هندسية (....) }
$$

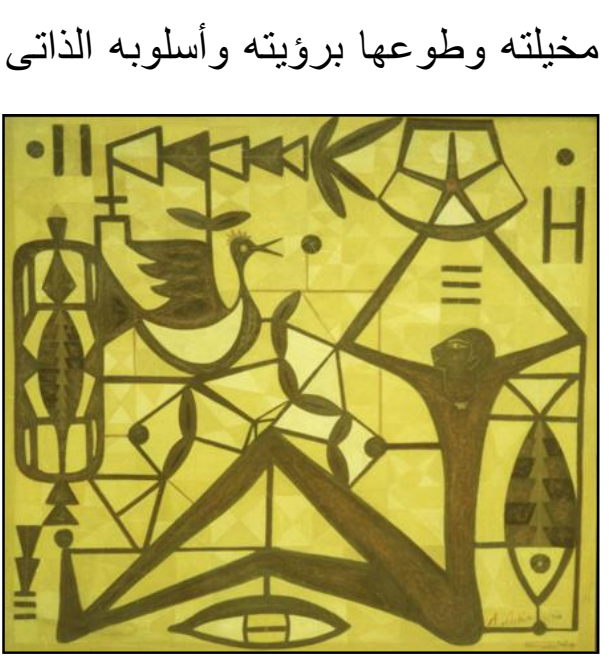

$$
\text { - - تاثر الفنان بالفن الشعبى و البيئة (الاستلهام): }
$$

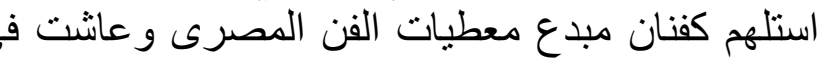

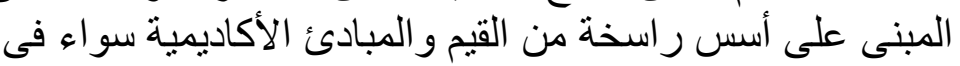

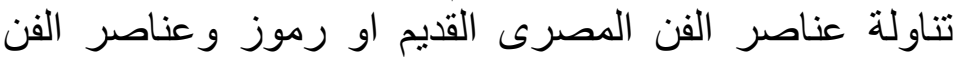

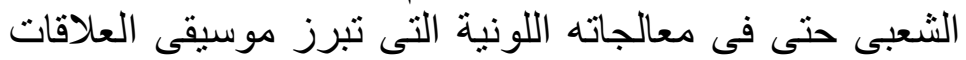
على مسطح اللوحة أو تكوينات العمل الفنى المتماسكة المحبوكة

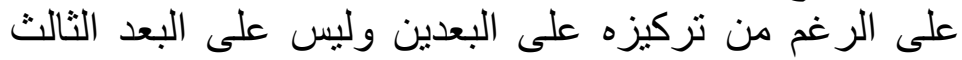

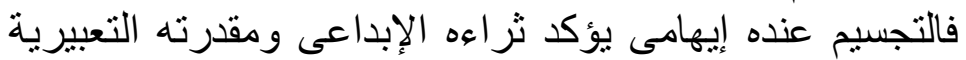
من خلال القيم الجمالية وشاعرية الحس وثراء الإعل الملامس

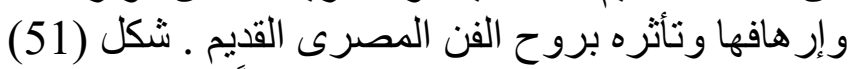

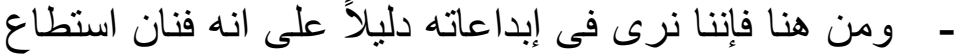

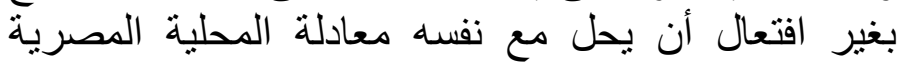

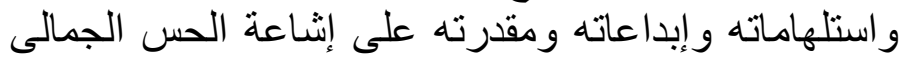
لاى المتلقى . 


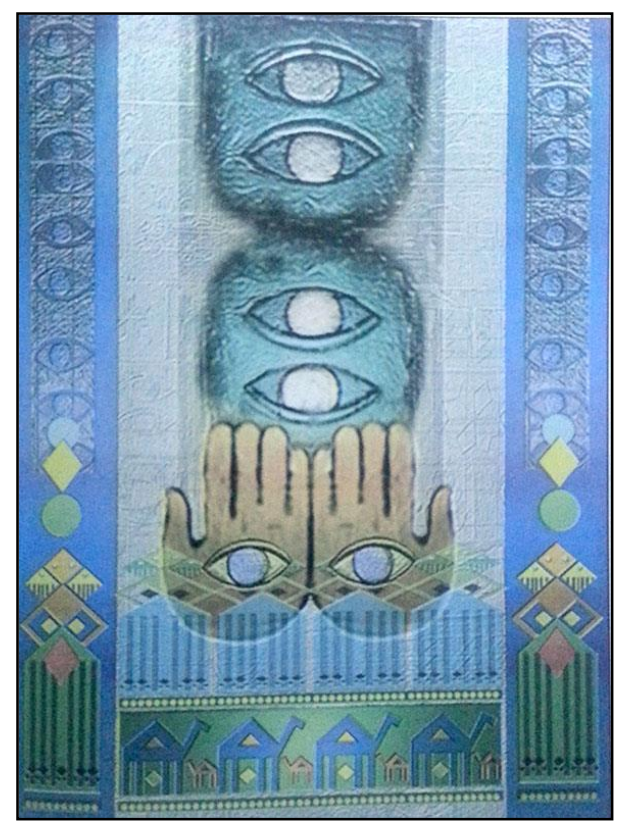

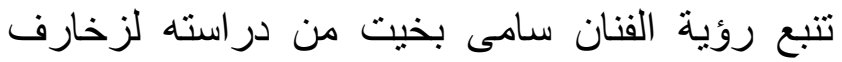

الحرف الثعبية المصرية التراثية ليعكس ذلك الونية الوعى بالذات

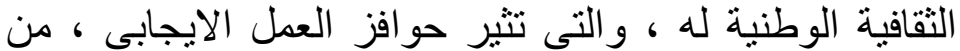

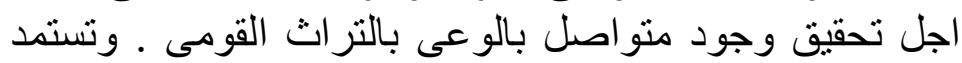

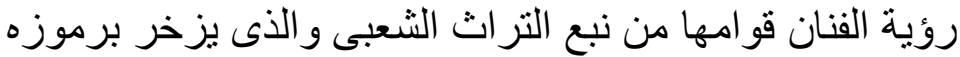

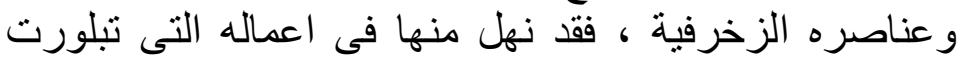

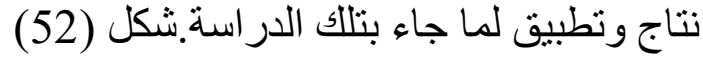

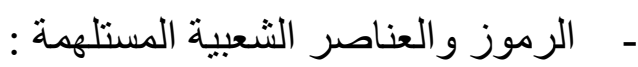

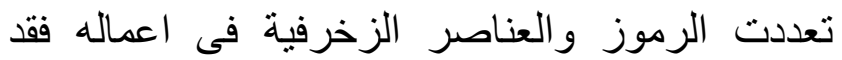
استلهم من الرموز و العناصر الشعبية التالية :

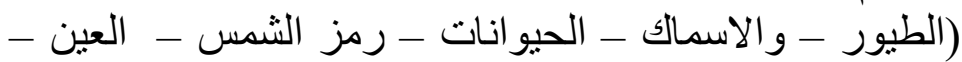
وكفة اليد ـ العر ائس و العناصر الكتابية )

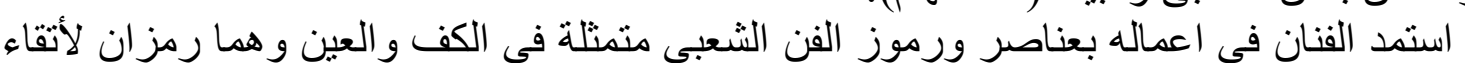

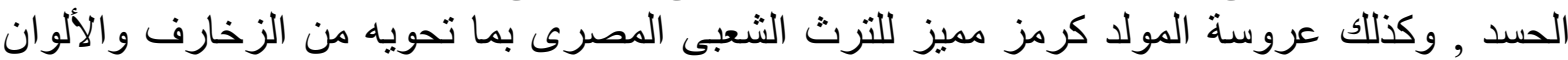

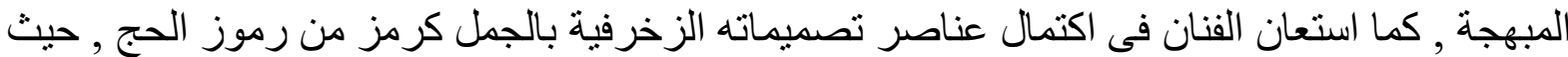

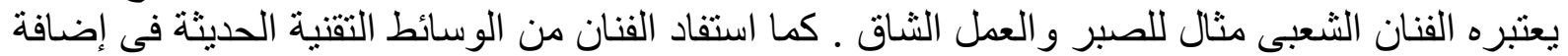

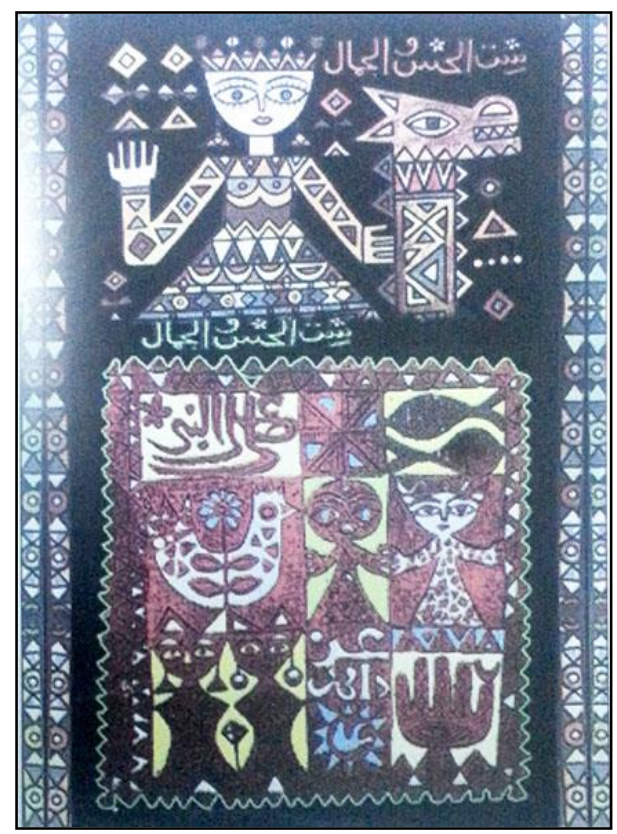

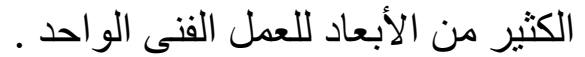

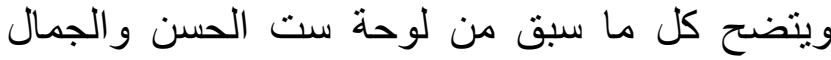

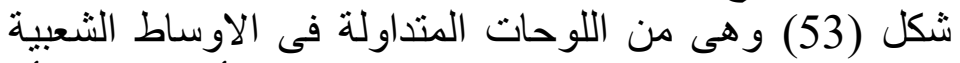

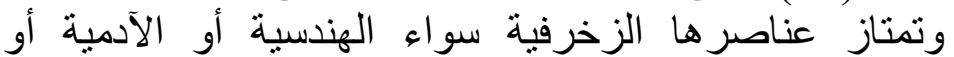

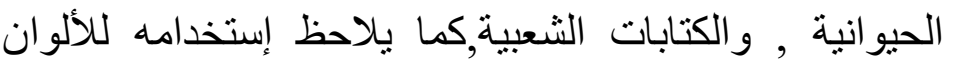

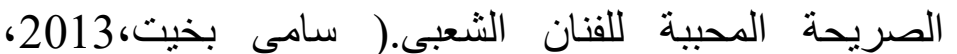

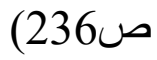
شكل (53) 
نتائج البحث : من خلال ما سبق عرضه فى هذا البحث توصلت الدر اسة للنتائج التالية :

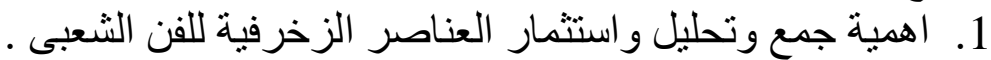

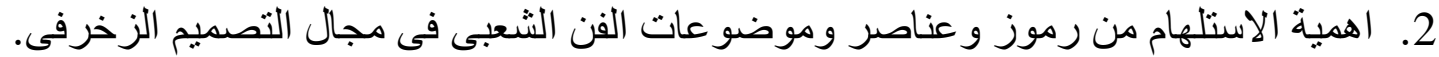

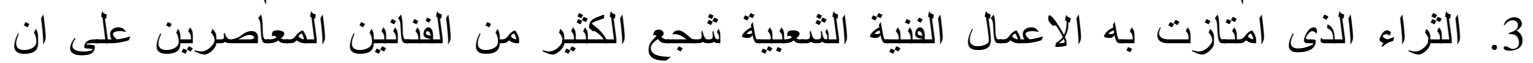

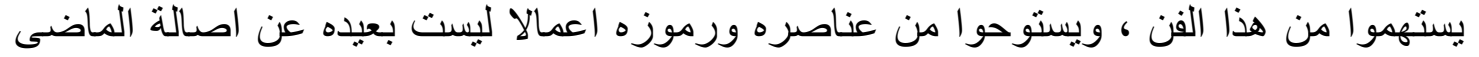

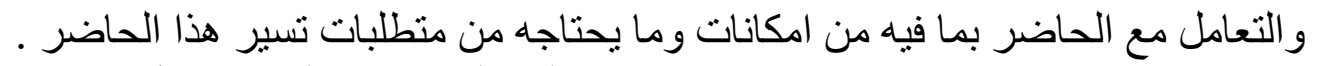

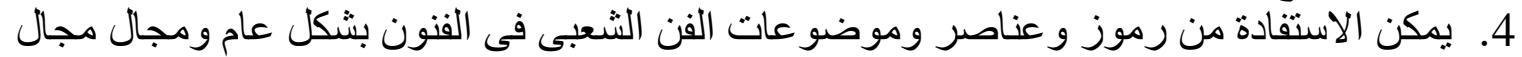

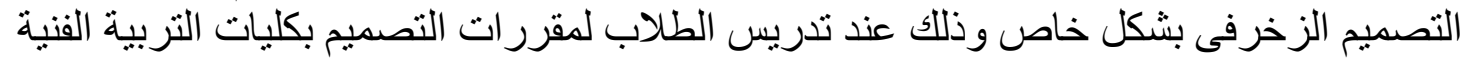

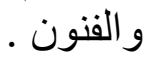

1. احمد زكى بدوى.(1991). معجم الدراسات الانسانية والفنون الجميلة والتشكيلية ، دار الكتاب المصرى و الكتاب اللبنانى : القاهرة ولبنان. 2. ريتا رمزى وديع غطاس.(1999). نظم الإيقاع الخطى فى بنية مختار ات من القو اقع البحرية كمدخل

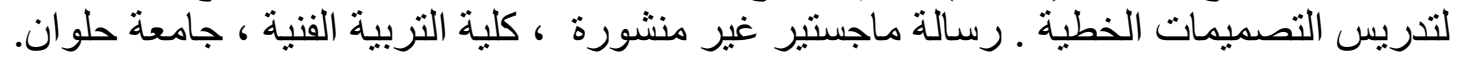

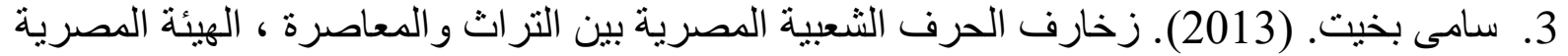

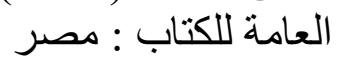
4. صبحى الثارونى.(10- 12-1989/11م) . مقابر الهو ، مجلة الفنون الثعبية ، العدد 29، الهيئة المصرية العامة للكتاب:مصر. 5. صفاء خميس شحاته.(4: 1989/8م). الفنان خميس شحاته ، مجلة الفنون الشعبية ، العدد 27-28،

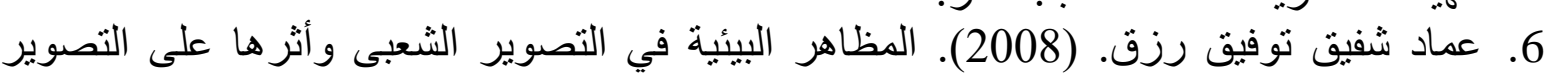

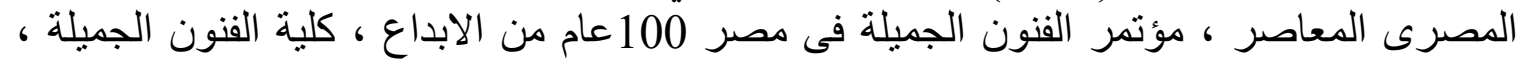
جامعة حلو ان ، مصر المر ، معرد 7. عمرو عبد القادر محمود. (2012). فنون بلاد النوبة ، عالم الكتب :مصر.

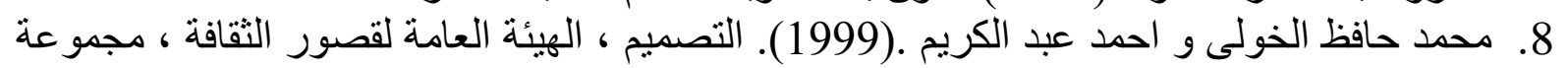

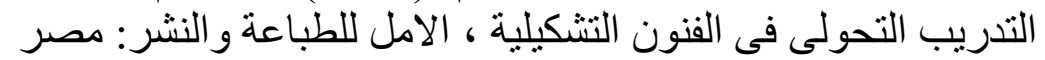

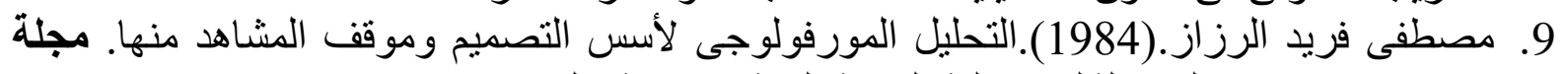

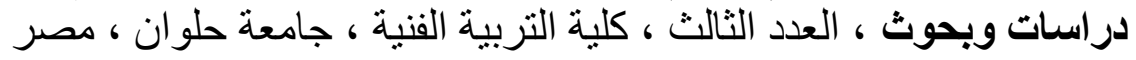




\section{Summary:}

"Folk Arts in the Egyptian environment as a source to enrich the decorative designs"

Dr. Barakat Saeed Mohammed

Design Assistant Professor - Department of Art Education - Faculty of Specific Education - University of

South

Valley

Folk arts are considered inherent arts of civilization and parallel to them. These arts still retain their traditions forming own personality of the surround the environment them. They are affected by all factors and events that revolve around them. Therefore, they are source of enrichment of decorative designs, whatever the raw material (natural or manufactured) or mediator that has differed as walls or attic or other securities.

Decorative design is an area of Fine Art in general and art education especially. Building composition of it sometimes depends on some elements of folk arts among the Egyptian environment having the richness and diversity of those elements of either plant, animal, engineering or other elements that have its Fine role on decorative designs and do not generate a vacuum because it is a part of human behavior.

This research aims to:

1- study of the importance of the elements of folk art derived from the environment.

2- recognize scope of haw to take advantage of folk arts of the Egyptian environment on decorative

designs of the ancient and Islamic Egyptian Civilizations.

Folk arts will continue to be a source of art springs, where artist benefits from all the time to produce his decorative design that enrich him aesthetically pleasing and expressive. Thus, artist will be get a pretty features and something special. Therefore decorative design will serve as an effective tool to regulate emotions and feeling. Because the decorative design imparts qualities and characteristics on its features of its contents, there is a closely relation between decorative design elements and folk arts derived from environment . 